IZA DP No. 5462

The Impact of Interest in School on Educational Success in Portugal

Pedro Goulart

Arjun S. Bedi

January 2011 


\title{
The Impact of Interest in School on Educational Success in Portugal
}

\author{
Pedro Goulart \\ ISS, Erasmus University Rotterdam \\ Arjun S. Bedi \\ ISS, Erasmus University Rotterdam, \\ ZEF and IZA
}
Discussion Paper No. 5462
January 2011

IZA

P.O. Box 7240

53072 Bonn

Germany

Phone: +49-228-3894-0

Fax: +49-228-3894-180

E-mail: iza@iza.org

\begin{abstract}
Any opinions expressed here are those of the author(s) and not those of IZA. Research published in this series may include views on policy, but the institute itself takes no institutional policy positions.

The Institute for the Study of Labor (IZA) in Bonn is a local and virtual international research center and a place of communication between science, politics and business. IZA is an independent nonprofit organization supported by Deutsche Post Foundation. The center is associated with the University of Bonn and offers a stimulating research environment through its international network, workshops and conferences, data service, project support, research visits and doctoral program. IZA engages in (i) original and internationally competitive research in all fields of labor economics, (ii) development of policy concepts, and (iii) dissemination of research results and concepts to the interested public.
\end{abstract}

IZA Discussion Papers often represent preliminary work and are circulated to encourage discussion. Citation of such a paper should account for its provisional character. A revised version may be available directly from the author. 


\begin{abstract}
The Impact of Interest in School on Educational Success in Portugal

Notwithstanding increased educational expenditure, Portugal continues to record poor educational outcomes. Underlining the weak expenditure-educational success link, a large body of work in educational economics displays that there is a tenuous relationship between a range of school inputs and cognitive achievement. Among others, the inability to establish a clear link between inputs and success has been attributed to the difficulty of controlling for unobserved attributes such as ability, motivation and interest. Against this background, and inspired by a large body of work in educational psychology which explicitly measures constructs such as educational motivation and interest, this paper examines whether a child's interest in school has any bearing on educational success after controlling for the kinds of variables typically used in educational economics analyses. We rely on two data sets collected in Portugal in 1998 and 2001 and examine the interest-educational success link using both cross-section and panel data. Our estimates suggest that after controlling for timeinvariant unobservable traits and for the simultaneous determination of interest and achievement, there is little support for the idea that prior interest in school has a bearing on future educational success.
\end{abstract}

JEL Classification: J24

Keywords: schooling, Portugal, educational outcomes, interest in school

Corresponding author:

Arjun S. Bedi

International Institute of Social Studies

Erasmus University Rotterdam

Kortenaerkade 12

2518 AX Den Haag

The Netherlands

E-mail: bedi@iss.nl 


\section{Introduction}

Educational attainment in Portugal lags considerably behind most European countries. The level of early school leavers is twice that of the European Union 15 (EU15) average and five times the average in New Member States (NMS). ${ }^{1}$ A substantial proportion of the difference in schooling attainment may be attributed to historical delays in educational investment, but even the younger generation appears to be lagging. For instance, the upper secondary school completion rate in Portugal is about a third of the EU15 average, while for youth aged 20-24 it is half of the European average. ${ }^{2}$

Despite continued public and private expenditure on education, currently 5.6 percent of GDP, which is slightly above the EU average (OECD, 2009), educational success remains elusive. ${ }^{3}$ While school enrolment is almost universal, schooling achievement is a source of concern. For example, a comparison of test scores in reading and Mathematics across seven countries shows that, relative to their peers, Portuguese children do not perform well. They are second from the bottom in terms of mathematical skills and are at the bottom of the chart in reading skills. ${ }^{4}$ Grade failure and repetition rates are high and our assessment of a nationally representative survey conducted in 2001 shows that at the age of 15, 63 percent of boys and 46 percent of girls have failed at least once during their tenure in school.

\footnotetext{
${ }^{1}$ EU15 refers to the 15 initial member states of the European Union, while the New Member States refers to recent entrants from Eastern Europe. The "early school leavers rate" is defined as the share of the population aged 18-24 with less than upper secondary education and who are no longer in education or training. The figure for Portugal is 41.1 percent while it is 18.1 percent for the EU15 and 7.5 percent for NMS.

${ }^{2}$ For the population as a whole, the upper secondary school completion rate is 20.6 percent for Portugal as compared to 64.6 percent for the EU 15 and 81 percent for NMS. For individuals in the age group 20-24 the rates are 47 percent for Portugal, 75 percent for the EU15 and 88.3 percent for the NMS.

${ }^{3}$ Educational expenditure as a percent of GDP rose from less than 1 percent in the mid-70s to about 3.5 percent in the mid-80s and to about 4.5 percent in the mid-90s (Goulart and Bedi, 2007).

4 The comparison countries are Spain, Ireland and Greece, as these countries are similar to Portugal in terms of their late entry into the EU and their relatively low levels of development at EU entry, and 4 NMS (Czech Republic, Hungary, Poland and Slovakia). A detailed comparison is provided in OECD (2003).
} 
As shown in the review by Krueger and Lindahl (2001), there is a strong link between educational attainment and growth at the micro and the macro level. While the literature on the relationship between cognitive achievement and labour market success is relatively limited, there is evidence from the United States (Murnane, et al., 1995; Jencks and Phillips, 1999; Rose, 2006) and internationally (Bedard and Ferrall, 2003) which shows that higher test scores are associated with higher earnings. Hanushek and Wößmann (2007) provide a recent review of the literature and argue that there is a strong link between test scores and individual earnings, income distribution and economic growth. ${ }^{5}$

Conversely, low levels of educational attainment and achievement are likely to have strong negative individual and social repercussions. For example, in the Portuguese context, incomplete compulsory schooling (less than 9 years) makes it impossible to obtain a driving licence and renders an individual ineligible for any form of public employment. Furthermore, increasing globalisation and the enlargement of the European Union has reinforced competitive pressures on the Portuguese economy. The structural backwardness of Portugal, particularly in terms of education, may depress economic growth and condemn large parts of the Portuguese population to low paying jobs or to unemployment (Carneiro, 2008). While the importance of cognitive skills for economic outcomes is clear, in Portugal where the school system is characterized by multiple failures and limited acquisition of cognitive skills, a pertinent question is, what measures may be taken to increase such skills?

There is a large body of research in education economics which controls for various child and household socio-economic characteristics and examines the effect of educational spending and the provision of additional schooling inputs on cognitive outcomes (test scores, failure, repetition). Typically, research in this genre treats

\footnotetext{
${ }^{5}$ In the current context, Pereira and Martins (2001) and Carneiro (2008) estimate that educational returns in Portugal lie between 8 and 12 percent.
} 
characteristics such as the educational motivation and interest of children and parents as unobserved attributes. In contrast, there is a large body of work in educational psychology that measures and places the role of a child's traits such as motivation, interest and self-perceptions of ability at the centre-stage in terms of determining educational outcomes. This literature also argues that the role of self-perceptions in driving educational success has policy implications as 'perceptions [are] often easier to change than environmental circumstances' (Denissen, et al., 2007). In a similar vein, Pajares and Schunk (2002, p.24) add, 'teachers should pay as much attention to students' motivation as to actual competence, for it is the belief that may accurately predict students' motivation and future academic choices'. ${ }^{6}$

While we engage with the conceptualization of such constructs later in the text, it seems fairly common-place to note that characteristics such as a child's motivation and interest should have a bearing on educational outcomes. However, it is only relatively recently that economists have started examining the effect of such qualities on a range of socioeconomic outcomes. Some of the early work comes from Bowles and Gintis (1976), Edwards (1976) and Bowles, et al. (2001) provide a survey of the literature on the role of personality traits in determining earnings. While results differ across studies there is clear evidence that personality traits have a bearing on earnings. More recently, Mueller and Plug (2006) account for a range of econometric concerns and examine the effect of the Big Five personality traits on earnings. ${ }^{7}$ Their analysis shows that returns to personality traits are comparable in magnitude to the earnings effects of cognitive abilities. On a similar note, Heckman, et al. (2006) study the role of cognitive and non-cognitive skills

\footnotetext{
${ }^{6}$ The three constructs, motivation, interest and self-perceptions of ability are closely linked and in section II we discuss motivation and interest, which are the focus of this paper, in some more detail. To add to the terminological complexity, the terms self-belief, self-concept and self-perceptions are terms used by different authors to communicate similar ideas.

${ }^{7}$ The Big Five factors are often condensed in the form of an acronym - OCEAN. These are Openness to experience, Conscientiousness, Extraversion, Agreeableness, Neuroticism.
} 
(locus of control and perceptions of self worth) on wages and conclude that the marginal effect of both sets of traits on wages is equally large while Heckman and Masterov (2007) show that the effect of personality and motivation on various socioeconomic outcomes persists over the life cycle of individuals who attended a preschool program.

In contrast, and as a complement to this emerging economics literature, the focus of this paper is on the effect of a non-cognitive attribute - child's interest in school on a cognitive outcome. ${ }^{8}$ The paper's focus on educational outcomes distinguishes it from the bulk of the emerging literature which tends to deal with adults and labour market outcomes. The focus on children provides a wider scope for policy intervention during the educational process (Link and Mulligan, 1996). For example, if such non-cognitive traits turn out to be important, programs that attempt to foster educational interest should be an integral component of programmes aimed at improving test scores.

Echoing the psychological literature, Borghans, et al. (2008) point out that personality traits are more malleable than cognitive ability and that social policy may be more actively used to develop traits that have a bearing on educational, labour market and other socioeconomic outcomes. However, without evidence on the predictive power and causal role of non-cognitive traits in influencing children's educational outcomes it is premature to raise policy issues, and the investigation of such a link is the main concern of this paper. ${ }^{9}$

This paper is organised as follows, section 2 briefly reviews the economics and psychology literature on the determinants of educational outcomes and conceptualizes educational interest. Section 3 discusses an analytical framework and the key econometric

\footnotetext{
8 Our examination is similar in spirit to the work by Borghans, et al. (2006) who use an experimental approach to examine the correlation/marginal effect of various personality traits on cognitive test scores of adults. Their work is based on 128 students at Maastricht University and shows that performancemotivation increases the probability of giving a correct answer by 7 to 10 percentage points. Their focus is on establishing the interaction between personality type and monetary incentives in promoting test scores and does not control for innate ability, parental or family background characteristics.

${ }^{9}$ For instance, it may be readily argued that educational interest and motivation are a consequence of educational success and do not cause educational success.
} 
concerns, while section 4 discusses the data. Section 5 provides an empirical analysis of the educational interest-educational success link, while section 6 concludes.

\section{Determinants of educational outcomes}

\section{II.1 The Economics literature}

There is a large economics literature which examines the link between school inputs and cognitive achievement after controlling for various child, household, peer and community characteristics. This educational production function literature, the origins of which may be traced to the Coleman Report (Coleman, et al., 1966), has been surveyed by Hanushek (1979), Hanushek (1986), Harbison and Hanushek (1992), Fuller and Clarke (1994), Glewwe (2002), Todd and Wolpin (2003) and most recently by Hanushek and Wößmann (2007) and Meghir and Rivkin (2011).

An examination of these surveys and individual studies shows that there is a great deal of uncertainty regarding the identification of factors that play a role in determining cognitive outcomes. ${ }^{10}$ Based on their review of the literature covering developing and developed countries, Hanushek and Wößmann (2007) conclude that while there are individual studies which display a positive effect of smaller classes, availability of textbooks and improvement of school facilities on cognitive outcomes, the main conclusion that may be drawn is that channeling additional resources along traditional lines such as reductions in class sizes or increases in teacher salaries is unlikely to lead to substantial changes in student performance.

In the Portuguese context, Hanushek and Luque (2003) use 1995 data from the Trends in International Mathematics and Science Study (TIMSS) and find that after controlling for family characteristics, school factors explain 7 percent of the variance in

\footnotetext{
10 For example, Fuller and Clarke (1994) report that only 9 out of 26 primary-school studies find a significant impact of class size on achievement in developing countries. Harbison and Hanushek (1992) examine the effect of teacher-pupil ratios and find that in 16 out of 30 papers with statistically significant effects, eight studies yield positive while eight studies yield negative effects. Hanushek (2003) provides an updated discussion which displays a similar pattern. .
} 
test scores. Similarly, based on the 2000 wave of the Programme for International Student Assessment (PISA) survey which contains information on test scores in reading, Maths and Science for 15 year olds, Carneiro (2008) concludes that the family background of children is the major observable factor driving variation in test scores while school resources have a "very limited role". At the same time he notes that a large proportion (about 55 to 60 percent) of the variance in student achievement may be attributed to unobserved characteristics.

Glewwe's (2002) survey focuses on methodological issues and argues that the bulk of the educational production function studies may not be credible as they do not deal with key econometric concerns. Chiefly, Glewwe (2002) points out that studies which attempt to link school inputs to learning outcomes do not (i) control for a child's innate ability and motivation (ii) parental motivation and ability to help their children (iii) unobserved school inputs such as teacher motivation and finally (iv) measurement error in the regressors.

While IQ tests have been used to measure and control for innate ability, it has been argued that any test which claims to measure a genetic endowment inevitably includes the effect of environmental factors (Glewwe, 2002) or constructed/learned ability (Strauss and Thomas, 1995) casting doubt on whether it is possible to control for inherent ability. An alternative and ingenious approach to control for innate ability, which is restricted to the few cases where data are available, has been to exploit data on twins (Behrman, et al., 1994; Card, 1999) or on adoptee samples (Sacerdote, 2002; Plug, 2004). A somewhat more approachable solution has been to use panel data to control for the effect of time invariant unobservables which may include innate ability (Link and Mulligan, 1996; Ballou et al. 2004; Tekwe et al. 2004; Rivkin et al., 2005).

In contrast to the numerous attempts that have been made to control for ability, the role of motivation and interest - whether it refers to the child, parent or teacher - in 
shaping educational outcomes has received far less attention in the educational economics literature. ${ }^{11}$ In contrast, a focus on such traits has been a key concern in the educational psychology literature.

\section{II.2 The Psychology literature}

Educational psychologists have intensively studied the effect of motivation in influencing educational outcomes. The focus of the literature is on the motivation of the individual directly engaged in the learning process, and motivational researchers deal with, "what moves people to act" (Wigfield, et al., 1998, p. 73). Typically, educational motivation has been characterized in terms of the choices students make about whether or not to engage in an academic activity, the desire to persist and re-engage with an academic activity and the degree of effort/time expended on such activities. Consistent with this characterization, in their review of the literature, Maehr and Meyer (1997) argue that the term "personal investment" maybe used as an alternative for motivation. They point out that motivation is "freighted with meanings that are difficult to defend", and that the term investment as seen in the "direction, intensity, persistence and quality" of an individual's actions characterizes motivation.

Motivation in turn is treated as a function of students' beliefs about their ability, their interest in and the value they place on academic activity. In this formulation, interest is referred to as intrinsic motivation, that is, "when individuals are intrinsically motivated, they engage in activities for their own sake and out of interest in the activity"

\footnotetext{
${ }^{11}$ Chagas Lopes and Goulart (2005) and Goulart and Bedi (2008) look at interest in school in the context of child labour.
} 
(Wigfield et al., 1998:77) while engagement in activities driven by their value or the incentives associated with engaging in such activities is termed as extrinsic motivation. ${ }^{12}$

Similar to the notion of motivation as "personal investment", Horn (1982) and Eccles (1983) argue that academic interest drives task choice and the investment of intellectual resources which in turn should translate into higher educational achievement. Predating their writings, Dewey (1913) argued that "if we can secure interest in a given set of facts or ideas, we may be perfectly sure that the pupil will direct his energies towards mastering them" (p.1). Dewey claimed that a strong interest will sustain an individual's attention and lead to sustained effort in accomplishing an academic goal. In terms of a definition, Renninger and Hidi (2002) define interest as 'a psychological state of having an affective reaction to and focused attention for particular content and/or the relatively enduring predisposition to re-engage particular classes of objects, events, or ideas' (Renninger and Hidi, 2002:174).

This characterization of educational interest in terms of attraction to a particular content, the desire to continually engage in a particular activity and the investment of time and effort is very similar to the characterisation of educational motivation. While the literature uses both terms, our reading of the literature suggests that the constructs educational motivation and educational interest are defined and characterized in very similar ways and are often used to express the same idea. Accordingly, for the purposes of this paper we will treat the two terms as synonyms.

At least three different self-reported survey based approaches have been used to measure educational interest. The most straightforward is a general single-dimension

\footnotetext{
${ }^{12}$ Extrinsic motivation refers to a situation where activities 'are performed not out of interest but because they are believed to be instrumental to some separable consequence' (Deci, et al., 1991:328). The intrinsicextrinsic dichotomy may suggest that intrinsic motivation is immutable. However, this is unlikely and as argued by Deci, et al. (1991) while external incentives may drive actions initially, it is possible that over time internalization occurs and leads to a breakdown of the dichotomy. Ryan and Stiller (1991) also argue against this dichotomy while Connell and Wellborn (1991) do not draw a distinction between interest and motivation.
} 
interest measure based on student responses to a question such as "I am interested in school" (True or False) or "I am satisfied with the way my education is going" (True or False) as used in the well known 'High School and Beyond' surveys (http://dx.doi.org/10.3886/ICPSR07896) or by asking respondents to rate their interest in school on a Likert scale (strongly disagree - strongly agree) in response to statements such as "I like being in school" or "School is interesting" (Huebner, 1994; Huebner and Gilman, 2006). Such single-dimension measures are more likely to be useful at younger ages, as younger children may not always be conscious of their interest in specific activities (Renninger and Hidi, 2002:177).

A more sophisticated approach comprises the collection of domain-specific measures, for example a child's interest in specific academic activities. This may be more relevant for older children. As argued by Wigfield et al. (1998:85) as children grow and discover their capacities and opportunities, interests tend to be more distinguishable and specific, rather than "universal" interests. Interests in specific academic subjects such as English, Math, Science are measured by asking children to rate their interest in each domain using a Likert scale. Typical statements are framed as "I find (domain X) very boring - very interesting" (for example, see Denissen et al. 2007).

A third method assesses interest by constructing a composite index of several questions which try and capture different dimensions. For example, the Quality of School Life Scale assesses satisfaction with school on the basis of 5 items and commitment to class work by 11 items (Epstein and McPartland, 1976). ${ }^{13}$ Another example is the "attitudes towards school index", which contains 17 items divided into

\footnotetext{
13 Satisfaction with school includes items such as "The school and I are like: Good friends; Friends; Distant relatives; Strangers; Enemies", "I like school very much: True or False" and "Most of the time I do not want to go to school: False or True". Commitment to class work includes, "Work in class is just busy work and a waste of time: Always to Never", "In class, I often count the minutes till it ends: False or True" and "The things I get to work on in most of my classes are: Great stuff - really interesting to me to Trash - a total loss to me".
} 
three content areas including attitude towards school assignments, perception of the learning process and perception of school climate (Beers, 1970; Kohr, 1975). Some authors use both domain specific measures and composite multidimensional indices (Marsh et al., 2005).

There is no agreement on the best way to measure interest, apart from the use of a broader measure of academic interest for younger children and the use of domainspecific measures for older children. However, the use of different measures involves trade-offs. The more complex measures - domain-specific and multi-dimensional indices allow a more nuanced analysis of interest but are time-intensive and this makes them less attractive in large scale surveys.

There are a range of studies which have examined the relationship between interest and persistent attention (Shirley and Reynolds, 1988; Hidi, 1990), academic choice (Holland, 1985), the acquisition of domain-specific knowledge (Alexander, et al., 1997) and most pertinently for this study, academic achievement. The main conclusion from the interest-academic achievement strand of work is that there is a positive relationship between achievement and interest with correlations ranging from 0.25 to 0.35 (Eccles et al., 1993; Wigfield, 1997; Reeve and Hakel, 2000; Marsh et al., 2005). On the basis of a meta-analysis, Schiefele et al. (1992) conclude that the correlation between interest and academic achievement is about 0.30. The link between interest and achievement is unlikely to be static and it has been argued that while interest and achievement may be quite distinct at an early age, due to the interaction between the two constructs they are likely to become increasingly intertwined as children mature (Wigfield and Eccles, 2002). For example, Denissen et al. (2007) use longitudinal data from Michigan to examine the link between interest and achievement for children between grades 1 and 12. Their analysis supports the strengthening of the link between these two constructs from a correlation of 0.13 in grade 1 to about 0.29 by grade 12 . 
A recent theme in the educational psychology literature has been a concern about the "causal ordering" between interest and achievement. That is, does interest precede achievement or does achievement precede interest. Marsh et al. (2005) study this link based on two databases of $7^{\text {th }}$ graders from Germany from whom data was collected at two points in the same academic year. Their analysis shows that while interest in Maths in period 1 is statistically significantly correlated with Maths test scores in period 2 (correlation is 0.09-0.10) there is limited support for the effect of test scores in period 1 on interest in period 2. Köller et al. (2001) also work with a sample of German students and find that mathematics interest in grade 7 has no effect on achievement in grade 10, while interest in grade 10 does influence achievement in grade 12. Thus, both these papers provide some support for the idea that interest precedes achievement.

While the educational psychology literature pays considerable attention to the role of a child's motivation in determining educational achievement, there are two issues about this body of work that need to be highlighted. First, there is little attempt to control for the role of a child's unobserved ability in influencing interest and achievement and second, almost none of the work controls for the role that may be played by individual, household and community characteristics in influencing achievement. Usually, the focus is squarely on the bivariate link between educational achievement and interest. This has not gone unnoticed and in their review of the literature, Maehr and Meyer (1997) point out that negligence of socio-cultural background differences is a "serious deficiency in the motivation literature". Despite raising this concern, there seems to be little attempt even in the most recent empirical work in this genre to control for differences in socio-economic background or to control for unobserved ability (Marsh et al., 2005; Denissen et al., 2007).

In this paper, drawing on the educational economics and educational psychology literature we examine the link between a typically unobserved attribute such as a child's 
interest in schooling and educational outcomes (never failed in school). Our analysis controls for several child, household, school and regional characteristics and is based on two household surveys collected in 1998 and 2001, which are representative of households with children in the age group 6 to 15. In addition, we exploit the panel element of the data to control for time-invariant unobserved heterogeneity. Since the surveys cover a large number of children and collect a considerable amount of information, the statistical agency conducting the survey opted for a general rather than a domain specific measure of interest, that is, a child's self-reported indication of a high, medium or low level of school interest. ${ }^{14}$ As we discuss below this measure yields estimates of the achievement-interest link which are consistent with those found in the psychological literature.

\section{An analytical framework}

In principle, credible estimation of a cognitive achievement relationship requires contemporaneous and past information on child, school and household characteristics and information on a child's unobserved abilities. Such detailed information is hard to obtain and a number of approaches may be used to mitigate some of the concerns. In this case, drawing on a well-established education economics literature the unobserved test scores of children $\left(Y^{*}\right)$ is treated as a function of child demographic $(C)$, child educational interest $(I)$, household demographic and socio-economic $(H)$, school input (S) and regional (R) characteristics. That is,

$$
Y_{i}^{*}=C_{i} \beta_{C}+I_{i} \beta_{I}+H_{i} \beta_{H}+S_{i} \beta_{S}+R_{i} \beta_{R}+\varepsilon_{i} .
$$

\footnotetext{
14 The question used to capture interest in school is, 'How is or was your relation with school?' 'The options are, (i) Good, very interested (ii) Fair (iii) Not attractive (iv) Bad. Since very few children opted for options (iii) and (iv), we reclassified the information into three categories, High level of interest (good, very interested), medium level of interest (fair) and a low level of interest (not attractive, bad). In the 1998 survey only children were asked to respond to this question while in the 2001 survey parents and children responded to this question.
} 
While the dataset does not contain information on children's test scores, we do observe whether a child has achieved educational success, that is, whether a child has never repeated grades. ${ }^{15}$ When test scores obtained by a student cross a certain threshold we observe school success $(Y=1)$. Thus, the probability that a child succeeds is,

$$
\operatorname{Pr} o b\left[Y_{i}=1\right]=\operatorname{Pr} o b\left[C_{i} \beta_{C}+I_{i} \beta_{I}+H_{i} \beta_{H}+S_{i} \beta_{S}+R_{i} \beta_{R}+\varepsilon_{i}>0\right] .
$$

Assuming a normally distributed error term allows estimation of (2) using a probit model.

The key difference between the specification outlined above and standard educational production function analyses is the inclusion of a typically unobserved attribute such as a child's interest in school as an additional regressor. The aim is to examine whether after controlling for a wide range of observed characteristics, constructs such as interest have a bearing on educational outcomes.

Despite being able to control for an array of parental, household and school input characteristics, there are several econometric issues that need to be dealt with before we may obtain credible estimates of child interest on educational outcomes. First, unobserved factors, such as a child's inherent ability, may be positively correlated with both interest in school and school success. If this is the case, then estimates based on (2) are likely to overestimate the effect of interest on educational success. Second, as discussed in section II, identifying the "causal ordering" of interest and educational success has been a substantial challenge in the psychology literature. Equation (2) treats educational success as a function of interest, however, it is equally likely that a child's interest in education is a function of educational success. In other words, educational success and interest are likely to be simultaneously determined. This notion is implicit in

\footnotetext{
15 The school success specification is estimated on the basis of information for all the children in the sample and is not a select sample of children who are still enrolled in school. The school enrolment rate in both years for which we have data is 97 to 98 percent and information on grade repetition is available for all children regardless of whether they are currently enrolled in school or not. School enrolment and regular school attendance are almost universal and hence the appropriate concern is the educational performance of children.
} 
the psychology literature where it is argued that as children age the correlation between interest and achievement tends to increase because "as the children mature cognitively they become better at regulating their behavioural investments according to their interests" (Denissen, et al., 2007, p. 430). Estimates which do not account for the possibly simultaneous determination of interest and success are likely to exaggerate the strength of the link.

Our empirical strategy to tackle the two issues outlined above is based on the creation of a panel data set. While details are provided later, we use the two cross-section data sets collected in 1998 and 2001 to create a panel of children living in households who were canvassed in both 1998 and 2001. The resulting sample is substantially smaller than the cross-section data sets but allows us to deal with some of the econometric concerns. With panel data at hand we may adopt a value-added specification, that is, achievement maybe treated as a function of contemporaneous child, school and family input measures and a lagged measure of achievement,

$$
Y_{i t}=C_{i t} \beta_{C}+I_{i t} \beta_{I}+H_{i t} \beta_{H}+S_{i t} \beta_{S}+R_{i t} \beta_{R}+\beta_{Y} Y_{i t-1}+\varepsilon_{i t}
$$

The motivation for (3) is that the inclusion of the lagged achievement measure serves as a control for past unobserved inputs and also controls for unobserved abilities. While such a value-added specification may yield some advantages over a contemporaneous specification (see Hanushek, 2003) estimates based on (3) are likely to be inconsistent as the lagged achievement measure will certainly be correlated with unobserved ability $\operatorname{Cov}\left(Y_{i t-1}, \varepsilon_{i t}\right) \neq 0$.

Alternatively, a panel data version of (2) for child $i$, time period $t$, may be written as:

$$
Y_{i t}=C_{i t} \beta_{C}+I_{i t} \beta_{I}+H_{i t} \beta_{H}+S_{i t} \beta_{S}+R_{i t} \beta_{R}+a_{i}+\varepsilon_{i t}
$$


where, $a_{i}$ denotes unobserved time-invariant child fixed effects. Estimates based on (4) provide an assessment of the link between educational interest and success after controlling for the effect of time-invariant observed and unobserved characteristics such as inherent ability/IQ that may influence both interest and school success. As long as inherent ability does not change rapidly over time a child fixed effects specification may be used to control for unobserved ability.

More explicitly, in differenced form (4) may be re-written as,

$$
\Delta Y_{i t}=\Delta C_{i t} \beta_{C}+\Delta I_{i t} \beta_{I}+\Delta H_{i t} \beta_{H}+\Delta S_{i t} \beta_{S}+\Delta R_{i t} \beta_{R}+\Delta \varepsilon_{i t} .
$$

While (5) controls for time-invariant attributes, if interest and educational success are simultaneously determined then estimates of the interest-educational success link are likely to be inconsistent, as even after controlling for $a_{i}, \operatorname{Cov}\left(\Delta I_{i t}, \Delta \varepsilon_{i t}\right)$ is unlikely to be zero.

To control for time-invariant characteristics and for potential simultaneity we estimate a version of (5) where change in educational success is treated as a function of lagged interest (interest measured in 1998). That is,

$$
\Delta Y_{i t}=\Delta C_{i t} \beta_{C}+I_{i t-1} \beta_{I}+\Delta H_{i t} \beta_{H}+\Delta S_{i t} \beta_{S}+\Delta R_{i t} \beta_{R}+\Delta \varepsilon_{i t} .
$$

If educational interest is formed in a manner that is sufficiently independent of contemporaneous educational achievement, then interest in 1998 should have a bearing on educational performance between 1998 and 2001. However, if interest is essentially a function of achievement and the two are simultaneously determined, then, after controlling for child fixed effects, interest in $1998\left(I_{i t-1}\right)$ is unlikely to have a bearing on changes in educational success between 1998 and 2001. Specification (6) is likely to yield consistent estimates of the interest-success link as it is based on the assumption that after controlling for $a_{i}$ and other time-varying observables, $\operatorname{Cov}\left(I_{i t-1}, \Delta \varepsilon_{i t}\right)$, is likely to be zero. 
That is, interest in 1998 is unlikely to be correlated with any unobserved time-varying unobservable characteristics that may influence achievement in $2001 .^{16}$

A final issue that needs to be confronted is the reliability of the interest measures. At least for the 2001 survey we have two reported measures of child interest, that is, responses from children on their interest in school and responses from parents on the interest of their child in school. Based on responses to these two questions and assuming the presence of classical measurement error it is possible to provide a sense of the reliability of the measure of child interest used in the paper. ${ }^{17}$ This allows us to gauge the extent to which measurement error has a bearing on the reported estimates. We discuss these effects later on in the text.

\section{Data, specification and descriptive statistics}

The paper relies on information contained in household surveys conducted in 1998 and 2001. These nationwide surveys which are representative of Portuguese households with children of school going age (6 to 15 years old) were canvassed by the Government in co-operation with the International Labour Organization. The 1998 survey covers 21,733 children while the 2001 survey covers 26,429 children. ${ }^{18}$ The surveys gathered information on the characteristics of children, their patterns of school attendance and success in school in terms of whether and how often they had failed a

\footnotetext{
${ }^{16}$ Estimates based on (5) will only be consistent if the assumption of strict exogeneity of the regressors, conditional on the unobserved fixed effect is satisfied. Given the potential simultaneity between interest and success this is unlikely to hold. In contrast, estimates based on (6) will be consistent if the assumption of sequential exogeneity is satisfied. That is, after conditioning on the unobserved fixed effect and other time-varying observables, past values of the regressors are not correlated with the error term. In the current application the latter assumption seems to be reasonable.
}

17 Suppose $I_{p}$ and $I_{c}$ represent observed measures of child interest as reported by parents and children, respectively. These two measures are designed to measure the unobserved trait child interest (I). Assuming classical measurement error $\left(I_{p}=I+e_{p} ; I_{c}=I+e_{c}\right)$, the reliability of any observable measure may be defined as the ratio of the true variance in $I$ divided by the total variance in an observed measure. That is $\operatorname{Var}(I) / \operatorname{Var}\left(I_{p}\right)$ or $\operatorname{Var}(I) / \operatorname{Var}\left(I_{c}\right)$. In this case the reliability ratio is the same as the correlation between $I_{p}$ and $I_{c}$. In our data the rank (Pearson) correlation between the two measures is $0.40(0.42)$. Additional discussions on measuring unobserved traits and classical measurement error are available in Ashenfelter and Krueger (1994) and Mueller and Plug (2006).

18 The 1998 survey was restricted to mainland Portugal while the 2001 survey covered the entire country. 
grade; information on the education and occupations of their fathers and mothers, household income and wealth. As discussed earlier, a relatively unusual aspect of the data is the availability of information on the educational interests of children in a data set that also has detailed information about individual and family characteristics. Information on educational interests of children was gathered in 1998, only from children, and in 2001 from both children and parents.

These survey data are supplemented with information on schooling inputs obtained from the Ministry of Education. These data are available at the regional level (28 regions) and were merged with the survey data so that we may control for variations in schooling inputs across regions. ${ }^{19}$ The school inputs cover several dimensions and include information on teacher characteristics (educational qualifications, type of contract), the number of students per teacher and the number of students per school.

School success is specified as a function of individual child characteristics which include among others, age, sex, child of household head, the time taken to reach school, whether a child attended pre-school and whether a child has a high, medium or low interest in school. The family/household traits are the educational attainment of the father and mother, family structure (single-parent family), household size and variables which capture household income and wealth. In addition, as described above the specification includes a range of school inputs as well as a set of controls for region and indicators for residing in urban, semi-rural and rural areas. Table 1 contains the detailed list of variables along with descriptive statistics for both 1998 and 2001.

\footnotetext{
19 While it may seem more appealing to have information at the level of the school, an advantage of regional level information is that it is less likely to be susceptible to household choice of school. Additionally, while we do include a range of school inputs, based on data collected in 2000, Carneiro (2008) shows that there is little variation in school inputs across Portugal. He reports that, hours of schooling per year, number of computers per students in a school, student-teacher ratio and the proportion of teachers with a degree in pedagogy does not differ across paternal schooling levels.
} 
At the time of designing the data collection exercise in 1998, the intention was to re-survey households in 2001 if at least one of their children remained in the age group 6 to 15. Based on information from the statistical agency responsible for data collection, a proportion of the households satisfying this criterion were re-surveyed in 2001. While survey invariant individual and household codes which may used to link surveyed units across years were not created it is possible to match households and children across surveys.

Table 2 describes the construction of the panel. We began by restricting ourselves to those households interviewed in 1998 who still had children in the age group 6 to 15 in 2001. This leads to a sample size of 13,623 children in 1998 and 18,536 in 2001. Subsequently, we focused on those children who were interviewed in the 2001 survey and who indicated they had lived in the same residence for at least 3 years. ${ }^{20}$ Finally, we matched children on the basis of number of rooms in their residence, child age and sex, maternal and paternal age and education. ${ }^{21} \mathrm{~A}$ total 1,812 children could be matched across the two surveys on these characteristics. Of these, for 1,733 children in 1998 and 1,682 children in 2001 we have relatively complete information and our panel data analysis relies on this sample of children.

An immediate question is whether such a panel data set which represents about 13 percent of the 1998 sample is systematically different from the larger cross-section data sets. For both 1998 and 2001, Table 3 provides descriptive statistics for the children who are in the panel data set and the cross-section data sets. In 1998, except for two variables (not a child of household head and the dummy for Alentejo region) none of the variables are substantially or statistically different between the larger and smaller data set.

\footnotetext{
${ }^{20}$ In the 2001 survey, respondents were asked to indicate how long they had lived at the address in which they were currently residing.

${ }^{21}$ Number of rooms in a house is restricted to bedrooms, living and dining rooms. WC, kitchen, corridors, balconies, storerooms are excluded.
} 
For 2001, as well, except for a handful of variables (not a child of household head, single-parent family, Alentejo and Algarve region dummies) all the other characteristics are not substantially or statistically different across the two data sets. The similarities are quite remarkable and suggest that children in the smaller data set are not systematically different from those in the larger data set and results based on such a panel data set are not driven by any special feature of the children comprising the panel. ${ }^{22}$

\section{Educational success and interest - estimates}

\section{V.1 Success and interest - a bivariate exploration using cross-section data}

The measure of educational success used in the paper is a binary variable and takes on a value 1 if a child has never repeated a grade in school and 0 otherwise. In both years, about 25 percent of the students have repeated a grade at least once. In terms of agespecific patterns, there are sharp variations and as shown in Table 4, as children age the level of success drops and by age 15 almost half the children have failed at least once.

The key variable in the current analysis is the educational interest of children. This information was gathered in 1998 by asking children to indicate their interest in school and then again in 2001 by asking children to indicate their interest and by asking parents to indicate the interest of their children in school. The responses are sorted into three categories that is, whether a child is (i) very interested in school - high (ii) medium level of interest in school (iii) is not interested in school - low. Child responses for 1998 and 2001, displayed in Table 5, show that responses across the two years is quite similar. In both years the largest proportion of the responses falls in the category of high level of school interest (66.6 percent in 1998 and 58.5 percent in 2001), followed by medium (28.1 percent in 1998 and 36.9 percent in 2001) and a very small proportion of children indicate that they are not interested in school $(5.3$ percent in 1998 and 4.6 percent in

\footnotetext{
22 Table A1 provides regression estimates based on the smaller and larger data sets and as expected while the estimates based on the smaller data sets are less precise the two sets of estimates are not substantially different from each other.
} 
2001). A comparison of parental and child responses in 2001 shows a strong similarity in the overall patterns. That is, a small proportion indicates a low level of interest (about 7 percent) while over 50 percent indicate a high level of interest. A concern associated with questions such as interest is that responses may be very unstable. However, as displayed in Tables 5, across both surveys and across children and parents, the broad patterns appear to be quite steady.

To further probe some of the patterns and differences, Table 6 provides a comparison of the responses of parents and children in 2001. About 64 percent of the responses provided by parents and children coincide. The main difference comes from two corresponding changes. About 16 percent of the children who classify themselves as very interested are placed in the medium category by their parents and a slightly smaller percentage (about 13 percent) indicate a medium level of interest but are placed in the highest category by their parents. The rank (Pearson) correlation between parental and child responses is $0.40(0.42)$.

A more interesting pattern is provided in terms of age dynamics. As children age the level of interest in school tends to decline. Based on the 1998 sample (see Table 7a), from a high level of interest in school of about 88 percent amongst six year olds, the figure falls to 52 percent (a decline of 36 percentage points) for 15 years olds. The share of those with a medium level of interest increases three-fold from 11 to about 37 percent while the share of those with a low level of interest increases about 11 fold. Child responses in 2001 (Table 7b) indicate a similar pattern of decline from 78 percent of six year olds indicating a high level of interest which evaporates rapidly and only about 42 percent (a decline of 36 percentage points) of 15 year olds indicate a similar level of interest. There is a high degree of similarity in age-interest dynamics across the two surveys suggesting that the single-dimension interest question does contain useful information and is not unduly unstable. 
We begin our examination of the link between interest and school success by computing the correlation between the two (Table 8). Based on child responses to interest, the correlation lies between 0.33 and 0.38. This figure is comparable to the correlation of 0.30 as reported in Schiefele's et al. (1992) meta-analysis. The correlation between educational success and parental evaluation of a child's interest is somewhat stronger (0.45) and suggests that parental responses are more tightly linked to performance as compared to children's reactions.

Restricting attention to children's responses, Table 9 provides an assessment of the link between school success and achievement for different age groups. The first point to note is that as children age the correlation between interest and school success becomes stronger. In 1998 it rises from a correlation of 0.15 for six year olds to 0.38 for 15 year olds. The corresponding figures in 2001 are 0.05 and 0.40 . This pattern of increasing alignment between interest and success is a feature that has been pointed out in the psychology literature (Denissen, et al., 2007) and suggests that interest and educational success are simultaneously determined. A closer look at the figures, focusing on patterns in 2001, shows that amongst six year olds, educational success and interest are weakly correlated. This is probably not surprising as tenure at school amongst six year olds has not been very long. However, it also suggests that at the beginning of a child's educational career interest may be independent of achievement. However, within a year, sharp differences begin to emerge. Amongst seven year olds, about a third of those with a low level of interest have already failed at least once and amongst 15 years olds with a low level of interest about 90 percent have failed at least once. The upshot of this exploratory analysis is that the measure of interest used here yields patterns and correlation that are very similar to those found in the educational psychology literature.

\section{V.2 Success and interest - a multivariate assessment}


So far, the analysis of the interest-school success link has been reminiscent of the approach used in the psychology literature. We now turn to a multivariate assessment. For both 1998 and 2001 we present estimates of the school success-interest link after controlling for child, household and school inputs. We begin with a parsimonious specification and then extend it to add various sets of variables.

As shown in Table 10, column 1 there is a strong link between interest in school and the probability of school success. Without the inclusion of any controls the marginal effect of high interest on school success is 56 percentage points while that for a medium level of interest is 23 percentage points. The inclusion of child demographic characteristics and especially parental schooling, household income and wealth characteristics leads to a sharp reduction in the effects of interest. The marginal effect of high interest drops by 20 percentage points to 0.36 , while that of medium interest falls by 9 percentage points to 0.14 . The final specification which controls for schooling inputs results in an additional, although relatively small reduction in the effect of interest.

The patterns observed in 2001 (Table 11) are remarkably similar, which inspires confidence about the quality of the data, and show that starting from a marginal effect of 53 and 27 percentage points for a high and medium level of interest respectively, the inclusion of various controls leads to a fifty percent dissipation in the interest effect. The main point emerging from this exercise is that focusing only on correlations without controlling for various other factors that are likely to have a bearing on the formation of interest and on school success is likely to exaggerate the effect of interest. The close to fifty percent reduction in the magnitude of the estimates, subsequent to the inclusion of covariates suggests that the correlation of 0.3 observed in the psychology literature is likely to be considerably overestimated.

Notwithstanding the reduction in the magnitude, it is still very large and statistically significant and prima facie the estimates suggest that a useful way to increase 
educational success may consist of developing programs to enhance children's interest in school. As discussed in section III, despite controlling for a number of observed characteristics, estimates based on cross-section data do not account for the role that may be played by unobserved child abilities and the simultaneous formation of interest and school success. To wrestle with these issues we turn to the panel data estimates.

\section{V.3 Panel data estimates}

Information on school success and interest in school for children who were in the age group 6 to 12 in 1998 and the same children three years later is provided in Table 12. As may be expected given the age-specific patterns discussed earlier the level of school success falls from about 87 to 75 percent over the three year span. As shown in more detail in Table 13, between the two time periods an additional 13 percent of children who had not failed in 1998, fail in the intervening period. There are some discrepancies, as 16 children (0.92 percent) who indicated that they had failed in 1998 are found in the category of never failed in $2001 .^{23}$ The decline in the level of interest is even sharper than the decline in school success. In 1998, 74 percent of the children expressed a high level of interest in school, however, by 2001 this figure falls to 55 percent. The shift is mainly due to a movement from high to medium levels of interest (27.5 percent).

To explore the relationship between interest and success which is purged of the effect of time-invariant unobservable heterogeneity we estimate (5), which controls for child fixed effects. Estimates in Table 15 (column 2) show that after controlling for child fixed-effects there is a strong link between interest in school and school success. A high or medium level of interest in school is associated with a 16 to 18 percentage point increase in school success. While the fixed-effect specifications yield estimates that are substantially smaller than the corresponding estimates based on pooled data or single-

${ }^{23}$ We exclude these children from the regression analysis. 
year estimates (at least for high level of school interest) the marginal effects remain substantial.

To account for both time-invariant unobserved heterogeneity and simultaneity we estimate (6), where change in school success is treated as a function of interest in 1998 and changes in other time-varying characteristics. The use of a differenced specification controls for the effect of unobserved heterogeneity while the use of lagged interest provides a measure which is determined prior to events which occur between 1998 and 2001. If the formation of interest in school precedes educational success and is not simultaneously determined with it then a high level of school interest in 1998 should have a bearing on educational performance in the intervening period (1998 and 2001). However, the estimates suggest otherwise (Table 15, specification 3). While the rest of the estimates are in the same range as in specification 2 , there is no effect of lagged interest on educational success. The effect of medium level of interest is now negative although not statistically significant while the effect of a high level of interest is positive (about 4 percentage points) and is statistically insignificant. Additional specifications (see Table A3, column 4) where difference in achievement between 1998 and 2001 is treated as a function of lagged value of interest yield the same results, that is, there is little evidence to support the idea that educational interest in 1998 has a bearing on change in achievement between 1998 and 2001.

The lack of a link supports the idea that interest and achievement are jointly determined, and that the large effects noted in the earlier specifications are driven by a feedback relationship between the two. Rather than arguing that low academic achievement is due to low levels of interest the counter argument that children have a low interest in school due to low performance is equally valid. Thus, from a policy perspective it is hard to argue that creating interest in school is likely to have a causal 
effect on educational success as the current investigation suggests that the two are inextricably linked.

In contrast, the role of school inputs in determining educational success is statistically significant and we find that increases in the qualification of teachers (decrease in the percentage of teachers with less schooling) and larger schools are associated with an increase in educational success. ${ }^{24}$

A final concern, as discussed in section III is that measurement error in the interest variable is likely to lead to attenuated estimates of the relationship between interest and achievement. The extent of the attenuation depends on the reliability of the observed variables used to measure the unobserved trait child interest. In the current case, assuming classical measurement error, the correlation between the two reported child interest measures available for the 2001 survey provides an estimate of the reliability ratio. The correlation between the two measures is 0.42 and using, $\hat{\beta}_{I}=\beta_{I} \hat{\rho}$, where $\hat{\rho}$ is the correlation between two measures of child interest we may adjust the estimated coefficient on interest (in Table 15, column 3), to yield a measurement error adjusted estimate. Accounting for the degree of attenuation yields a marginal effect of 8.6 percentage points. Alternatively, one may treat the estimated coefficient on interest as the lower bound and the measurement adjusted coefficients as the upper bound of $\beta_{I}$. Thus, at best, a high interest in school is likely to translate into an imprecisely estimated 8-9 percentage point effect on achievement.

\section{Concluding remarks}

\footnotetext{
${ }^{24}$ A 5 percentage point reduction in temporary contracts is associated with a 3 percentage point increase in educational success while a larger number of pupils per school translates into higher educational success. For example, an increase in average school size by 50 students is associated with a 4 percentage point increase in educational success. The link between achievement and school size is interesting as in 20102011 the Portuguese schooling system underwent a major change. Following demographic and locational changes in the population, around 700, mainly primary schools were closed and 10,000 students moved into larger schools. Although, the mechanism is not clear, our results suggest that such a move may be associated with an increase in educational achievement.
} 
Motivated by the challenge of identifying and expanding policy-relevant ways of increasing educational success this paper drew inspiration from the differential emphases of the educational economics and educational psychology literature. While the educational economics literature emphasises the role of educational inputs and controls for a wide variety of child, family and community factors which may influence cognitive outcomes it tends to ignore the effect of child, parent and teacher interest and motivation in shaping outcomes. On the other hand the educational psychology literature places the role of constructs such as motivation and interest in influencing school achievement at the centre-stage but does not account for the role of other influences.

This paper drew on both strands of the literature and based on cross-section and panel data from Portugal examined the effect of a child's educational interest, after controlling for a variety of other influences, including school inputs on children's educational success. Estimates based on two cross-section data sets showed that there was a statistically strong and substantial effect of a high level of interest in school on success - a marginal effect ranging between 25 and 33 percentage points (Tables 10 and 11). However, accounting for the potential role of time-invariant ability on both interest and success led to a downward revision of this estimate - a marginal effect of 18 percentage points (Table 15) while accounting for both time-invariant ability and the simultaneous determination of interest led to a dissipation of the effect - a statistically insignificant and small effect of about 4 percentage points. Overall, the estimates presented in this paper suggest that the strong interest-success link noted in the educational psychology literature does not translate into a causal relationship.

In contrast to the work in this thesis, Martins (2010) finds a positive impact of raising interest in school on school achievement by researching the work of EPIS. ${ }^{25}$ This

\footnotetext{
${ }^{25}$ EPIS stands for Empresários pela Inclusão Social (Businessmen for Social Inclusion). The association mobilises resources to tackle school failure through a miriad of interventions involving children, parents and teachers.
} 
author controls for and refutes a possible explanation for the positive association, the effect of children feeling they were in an experience and perform better because of that the Hawthorne effect. However, EPIS consists of a large bundle of different interventions with different type of effects, which makes hard to ascribe an increase in achievement to an increase in interest of the child or to only one of the attributes of the programme. Additionally, because the EPIS programme involves children, parents and children alike it is difficult to disentangle the effect of each of their motivations, while our paper tackles only one element of motivation, the child's and does not account for teacher and parental motivation.

Our paper was inspired by the possibility that concepts such as interest and motivation may provide an important policy lever to influence educational success. Our analysis shows that interest and success are simultaneously determined and that educational interest and motivation are a consequence of success rather than vice-versa. 


\section{References}

Alexander, P.A., P.K. Murphy, B.S. Woods, K.E. Duhon, and D. Parker (1997) "College instruction and concomitant changes in students' knowledge, interest, and strategy use: A study of domain learning." Contemporary Educational Psychology, 22(2): 125-46.

Ashenfelter, O. and A. Krueger (1994) "Estimates of the economic return to schooling from a new sample of twins." American Economic Review, 84(5): 1157-73.

Ballou, D., W. Sanders, and P. Wright (2004) "Controlling for Student Background in Value-Added Assessment of Teachers." Journal of Educational and Behavioral Statistics, 29(1): 37-65.

Bedard, K. and C. Ferrall (2003) "Wage and test score dispersion: Some international evidence." Economics of Education Review, 22(1): 31-43.

Beers, J.S. (1970) "Educational Quality Assessment. Phase II findings: The ten goals of quality education.": Harrisburg.

Borghans, L., A.L. Duckworth, J.J. Heckman, and B.t. Weel (2008) "The Economics and Psychology of Personality Traits." IZA Discussion Paper, 3333.

Borghans, L., H. Meijers, and B. ter Weel (2006) "The Role of noncognitive skills in explaining cognitive test scores." IZA Discussion Paper, 2429.

Bowles, S. and H. Gintis (1976) Schooling in Capitalist America: Educational Reform and the Contradictions of Economic Life. New York: Basic Books.

Bowles, S., H. Gintis, and M. Osborne (2001) "The determinants of earnings: a behavioral approach." Journal of Economic Literature, 39(4): 1137-76.

Brunello, G. and D. Checchi (2005) "School quality and family background." Economics of Education Review, 24(5): 563-77.

Carneiro, P. (2008) "Inequality of Opportunity and Educational Achievement in Portugal." Portuguese Economic Journal, 7: 17-41.

Chagas Lopes, M. and P. Goulart (2005) "Educação e Trabalho Infantil em Portugal." IEFP: Lisbon.

Coleman, J., E. Campbell, C. Hobson, J. McPartland, A. Mood, F. Weinfield, and R. York (1966) "Equality of Educational Opportunity." US Government Printing Office: Washington D.C.

Connell, J.P. and J.G. Wellborn (1991) "Competence, autonomy, and relatedness: A motivational analysis of self-system processes," in Minnesota symposia on child psychology R. Gunnar and L.A. Sroufe, eds. Hillsdale, NJ: Erlbaum: 43-77.

Deci, E.L., R.J. Vallerand, L.G. Pelletier, and R.M. Ryan (1991) "Motivation and Education: The Self-Determination Perspective." Educational Psychologist, $26(3$ \& 4): $325-46$.

Denissen, J.J.A., N.R. Zarrett, and J.S. Eccles (2007) "I Like to Do It, I'm Able, and I Know I Am: Longitudinal Couplings Between Domain-Specific Achievement, SelfConcept, and Interest." Child Development, 78(2): 430-47.

Dewey, J. (1913) Interest and Effort in Education. Cambridge, MA: Riverside Press.

Eccles, J.S. (1983) "Expectancies, values, and academic behavior. ," in Achievement and achievement motivation. J.T. Spencer, ed. San Francisco: W.H. Freeman.

Eccles, J.S., A. Wigfield, C. Midgley, D. Reuman, D.M. Iver, and H. Feldlaufer (1993) "Negative Effects of Traditional Middle Schools on Students' Motivation." The Elementary School Journal, 93(5): 553-74.

Edwards, R.C. (1976) "Individual traits and organizational incentives: What makes a "good" worker? ." Journal of Human Resources 11(1): 51-68.

Epstein, J.L. and J.M. McPartland (1976) "The Concept and the Measurement of the Quality of School Life." American Educational Research Journal, 13(1): 15-30. 
Fuller, B. and P. Clark (1994) "Raising school effects while ignoring culture? Local conditions and influence of classroom tools, rules and pedagogy." Review of Educational Research, 64(1): 119-57.

Glewwe, P. (2002) "Schools and Skills in Developing Countries : Education Policies and Socioeconomic Outcomes." Journal of Economic Literature, 40(2): 436-82.

Goulart, P. and A.S. Bedi (2007) "A History of Child Labour in Portugal." ISS Working Paper, 448.

Goulart, P. and A. S. Bedi (2008) "Child Labour and Educational Success in Portugal." Economics of Education Review, 27(5): 575-87.

Hanushek, E.A. (1979) "Conceptual and Empirical Issues in the Estimation of Educational Production Functions." Journal of Human Resources, 14(3): 351-88.

Hanushek, E.A. (1986) "The economics of schooling: Production and efficiency in public schools." Journal of Economic Literature, 24(3): 1141-77.

Hanushek, E.A. (2003) "The Failure of Input-based Schooling Policies." Economic Journal, 113(485): F64-F98.

Hanushek, E.A. and J.A. Luque (2003) "Efficiency and equity in schools around the world." Economics of Education Review, 22(5): 481-502.

Hanushek, E.A. and L. Wößmann (2006) "Does Educational Tracking Affect Performance and Inequality? Differences-in-Differences Evidence Across Countries." Economic Journal, 116(510): C63-C76.

Harbison, R.W. and E.A. Hanushek (1992) Educational Performance of the Poor. Lessons from Rural Northeast Brazil. Washington DC: World Bank.

Heckman, J.J. and D.V. Masterov (2007) "The productivity argument for investing in young children." Review of Agricultural Economics 29(3): 446-93.

Heckman, J.J., J. Stixrud, and S. Urzua (2006) "The Efects of Cognitive and Noncognitive Abilities on Labor Market Outcomes and Social Behavior." Journal of Labor Economics, 24(3): 411-82.

Hidi, S. (1990) "Interest and Its Contribution as a Mental Resource for Learning." Review of Educational Research 60(4): 549-71.

Holland, J.L. (1985) Making vocational choices: A psychology of careers. Englewood Cliffs, NJ: Prentice-Hall.

Horn, J.L. (1982) "The theory of fluid and crystallized intelligence in relation to concepts of cognitive psychology and aging in adulthood," in Aging and cognitive processes F. I. M. Craik and S. Trehub, eds. New York: Plenum: 237 - 78.

Huebner, E.S. (1994) "Preliminary development and validation of a multidimensional life satisfaction scale for children." Psychological Assessment, 6(2): 149-58.

Huebner, E.S. and R. Gilman (2006) "Students who like and dislike school." Applied Research in Quality of Life, 1(2): 139-50.

Jencks, C. and M. Phillips (1999) "Aptitude or Achievement: Why do test scores predict educational attainment and earnings?," in Earning and learning: How schools matter. S.E. Mayer and P.E. Peterson, eds. Washington D.C.: Brookings Institution Press: 15-47.

Kohr, R.L. (1975) "A longitudinal study of selected cognitive and non-cognitive student outcomes from grade 5 to grade 9." Annual Meeting of the American Educational Research Association: Washington, D.C.

Köller, O., J. Baumert, and K. Schnabel (2001) "Does Interest Matter? The Relationship between Academic Interest and Achievement in Mathematics." Journal for Research in Mathematics Education, 32(5): 448-70.

Krueger, A.B. and M. Lindahl (2001) "Education for Growth: Why and For Whom?" Journal of Economic Literature, 39(4): 1101-36. 
Link, C.R. and J.G. Mulligan (1996) "The value of repeat data for individual students," in Assessing Educational Practices: The Contribution of Economics. W.J. Baumol and W.E. Becker, eds. Cambridge, MA: The MIT Press.

Maehr, M. and H. Meyer (1997) "Understanding Motivation and Schooling: Where We've Been, Where We Are, and Where We Need to Go." Educational Psychology Review, 9(4): 371-409.

Marsh, H.W., U. Trautwein, O. Lüdtke, O. Köller, and J. Baumert (2005) "Academic Self-Concept, Interest, Grades, and Standardized Test Scores: Reciprocal Effects Models of Causal Ordering." Child Development, 76(2): 397-416.

Martins, P.S. (2011) "Can Targeted, Non-Cognitive Skills Programs Improve Achievement? Evidence from EPIS." Paper presented at the First Lisbon Research Workshop on Economics and Econometrics of Education.

Meghir, C. and S. Rivkin (2011) "Econometric methods for research in education," in Handbooks in Economics: Economics of Education. E.A. Hanushek, S. Machin and L. Woessmann, eds. Amsterdam: North-Holland: 1-87.

Mueller, G. and E. Plug (2006) "Estimating the effect of personality on male and female earnings." Industrial and Labor Relations Review, 60(1): 3-22.

Murnane, R.J., J.B. Willett, and F. Levy (1995) "The growing importance of cognitive skills in wage determination." Review of Economics and Statistics, 77(2): 251-66.

OECD (2003) Learning for tomorrow's world-First results from PIS A 2003. Paris: OECD.

OECD (2009) Education at a Glance. Paris: OECD.

Pajares, F. and D.H. Schunk (2002) "Self and Self-Belief in Psychology and Education: An Historical Perspective," in Improving Academic Achievement. J. Aronson, ed. New York: Academic Press.

Pereira, P.T. and P.S. Martins (2001) "Portugal," in Education and earnings in Europe. C. Harmon, I. Walker and N. Westergaard-Nielsen, eds. Cheltenham, UK: Edward Elgar.

Plug, E. (2004) "Estimating the Effect of Mother's Schooling on Children's Schooling using a Sample of Adoptees." American Economic Review, 94(1): 358-68.

Reeve, C.L. and M.D. Hakel (2000) "Toward an understanding of adult intellectual development: Investigating within-individual convergence of interest and knowledge profiles." Journal of Applied Psychology, 85(6): 897-908.

Renninger, K.A. and S. Hidi (2002) "Student Interest and Achievement: Developmental Issues Raised by a Case Study," in Development of Achievement Motivation. A. Wigfield and J.S. Eccles, eds. London: Academic Press.

Rivkin, S.G., E.A. Hanushek, and J.F. Kain (2005) "Teachers, schools and economic achievement." Econometrica, 73(2): 417-58.

Rose, H. (2006) "Do gains in test scores explain labor market outcomes?" Economics of Education Review, 25(4): 430-46.

Rosenzweig, M.R. and K.I. Wolpin (1994) "Are There Increasing Returns to the Intergenerational Production of Human Capital? Maternal Schooling and Child Intellectual Achievement." Journal of Human Resources, 29(2): 670-94.

Ryan, R.M. and J. Stiller (1991) "The social contexts of internalization: Parent and teacher influences on autonomy, motivation and learning," in Advances in motivation and achievement. M.L. Maehr and P.R. Pintrich, eds. Greenwich, CT: JAI Press.

Sacerdote, B. (2002) "The nature and nurture of economic outcomes." American Economic Review, Papers and Proceedings, 102(2): 344-48.

Schiefele, U., A. Krapp, and A. Winteler (1992) "Interest as a predictor of academic achievement: A meta-analysis of research," in The role of interest in learning and development. K. A. Renninger, S. Hidi and A. Krapp, eds. Hillsdale, NJ: Lawrence Erlbaum: 183-212. 
Shirley, L.L. and R.E. Reynolds (1988) "Effect of interest on attention and learning." Journal of Educational Psychology, 80: 159-66.

Strauss, J. and D. Thomas (1995) "Human resources: empirical modelling of household and family decisions," in Handbook of Development Economics. Jere R. Berhman and T.N. Srinavasan, eds. Amsterdam: North Holland.

Tekwe, C.D., R.L. Carter, C.-X. Ma, J. Algina, M.E. Lucas, J. Roth, M. Ariet, T. Fisher, and M.B. Resnick (2004) "Performance An Empirical Comparison of Statistical Models for Value-Added Assessment of School." Journal of Educational and Behavioral Statistics, 29(1): 11-36.

Todd, P.E. and K.I. Wolpin (2003) "On the specification and estimation of the production function for cognitive achievement." Economic Journal, 113(485): F3-F33.

Wigfield, A. (1997) "Reading motives: A domain-specific approach to motivation." Educational Psychologist, 32(2): 59-68.

Wigfield, A. and J.S. Eccles (2002) "The development of competence beliefs, expectancies for success, and achievement values from childhood through adolescence," in Development of achievement motivation. A. Wigfield and J.S. Eccles, eds. San Diego, CA: Academic Press.: 173-95.

Wigfield, A., J.S. Eccles, and D. Rodriguez (1998) "The Development of Children's Motivation in School Contexts." Review of Research in Education, 23(1): 73-118. 
Table 1

Descriptive statistics

\begin{tabular}{|c|c|c|c|c|c|c|c|c|}
\hline \multirow{2}{*}{ Variables } & \multicolumn{4}{|c|}{1998} & \multicolumn{4}{|c|}{2001} \\
\hline & Mean & Std. Dev. & Min & Max & Mean & Std. Dev. & Min & Max \\
\hline School outcomes & & & & & & & & \\
\hline School success $=1$ & 0.750 & 0.433 & 0 & 1 & 0.748 & 0.434 & 0 & 1 \\
\hline Child characteristics & & & & & & & & \\
\hline Sex $($ Male $=1)$ & 0.511 & 0.499 & 0 & 1 & 0.513 & 0.499 & 0 & 1 \\
\hline Age & 11.001 & 2.908 & 6 & 15 & 10.90 & 2.790 & 6 & 15 \\
\hline Not child of household head $=1$ & 0.079 & 0.270 & 0 & 1 & 0.072 & 0.259 & 0 & 1 \\
\hline Pre-school attendance $=1$ & . & . & . & . & 0.725 & 0.446 & 0 & 1 \\
\hline Time to reach school & . & . & . & . & 1.369 & 0.703 & 0 & 5 \\
\hline Child interest in school - low & 0.053 & 0.224 & 0 & 1 & 0.046 & 0.209 & 0 & 1 \\
\hline Child interest in school - medium & 0.281 & 0.449 & 0 & 1 & 0.368 & 0.482 & 0 & 1 \\
\hline Child interest in school - high & 0.666 & 0.471 & 0 & 1 & 0.585 & 0.492 & 0 & 1 \\
\hline Household characteristics & & & & & & & & \\
\hline Father's schooling - 5 to 9 years $=1$ & 0.273 & 0.445 & 0 & 1 & 0.316 & 0.465 & 0 & 1 \\
\hline Father's schooling $->9$ years $=1$ & 0.144 & 0.351 & 0 & 1 & 0.143 & 0.350 & 0 & 1 \\
\hline Mother's schooling - 5 to 9 years $=1$ & 0.289 & 0.453 & 0 & 1 & 0.348 & 0.476 & 0 & 1 \\
\hline Mother's schooling - $>9$ years $=1$ & 0.161 & 0.367 & 0 & 1 & 0.171 & 0.376 & 0 & 1 \\
\hline Single-parent family $=1$ & 0.088 & 0.283 & 0 & 1 & 0.104 & 0.305 & 0 & 1 \\
\hline Household size & 4.399 & 1.281 & 2 & 12 & 4.411 & 1.318 & 2 & 12 \\
\hline Household income $(1-7$, increasing in & & & & & & & & \\
\hline income) & 3.988 & 1.677 & 1 & 7 & 4.430 & 1.627 & 1 & 7 \\
\hline Reduction in income $=1$ & . & . & . & . & 0.137 & 0.343 & 0 & 1 \\
\hline Number of rooms in house & 3.897 & 1.215 & 1 & 10 & 3.944 & 1.209 & 1 & 10 \\
\hline Adequate housing conditions $=1$ & 0.294 & 0.455 & 0 & 1 & 0.292 & 0.454 & 0 & 1 \\
\hline Good housing conditions $=1$ & 0.593 & 0.491 & 0 & 1 & 0.623 & 0.484 & 0 & 1 \\
\hline Have a small plot of land = 1 & . & . & . & . & 0.448 & 0.497 & 0 & 1 \\
\hline School characteristics & & & & & & & & \\
\hline Teachers with bachelor's degree or less & 0.387 & 0.275 & 0.147 & 0.858 & 0.305 & 0.218 & 0.087 & 0.787 \\
\hline Teachers with temporary contracts & 0.174 & 0.093 & 0.000 & 0.390 & 0.179 & 0.087 & 0.000 & 0.386 \\
\hline Pupils per teacher & 12 & 2.555 & 8 & 17 & 11 & 4.197 & 4 & 18 \\
\hline Pupils per school & 217 & 143.436 & 16 & 695 & 202 & 124.384 & 15 & 547 \\
\hline Regional & & & & & & & & \\
\hline Norte region & 0.417 & 0.493 & 0 & 1 & 0.413 & 0.492 & 0 & 1 \\
\hline Centro region & 0.251 & 0.434 & 0 & 1 & 0.177 & 0.382 & 0 & 1 \\
\hline Lisboa region & 0.219 & 0.414 & 0 & 1 & 0.175 & 0.379 & 0 & 1 \\
\hline Alentejo region & 0.082 & 0.275 & 0 & 1 & 0.082 & 0.275 & 0 & 1 \\
\hline Algarve region & 0.030 & 0.172 & 0 & 1 & 0.080 & 0.272 & 0 & 1 \\
\hline Rural municipality & 0.257 & 0.437 & 0 & 1 & 0.240 & 0.427 & 0 & 1 \\
\hline Peri-urban municipality & 0.344 & 0.475 & 0 & 1 & 0.368 & 0.482 & 0 & 1 \\
\hline Urban municipality & 0.400 & 0.490 & 0 & 1 & 0.384 & 0.486 & 0 & 1 \\
\hline
\end{tabular}

Note: In 1998, the sample is restricted to children residing in mainland Portugal. School variables are defined at the level of 28 regions, with the exception of pupils per school which is defined at the level of the country (278 counties). In 1998, $N=21,729$ for the school interest variables; 21,733 for the rest of the variables except for school characteristics where $N=21,277$. In 2001, $N=26,392$, with the exception for the schooling variables where $\mathrm{N}=23,975$.

Table 2

Construction of panel data

\begin{tabular}{|c|l|c|c|}
\hline \multirow{2}{*}{ Samples } & \multicolumn{1}{|c|}{ Description } & \multicolumn{2}{c|}{ Observations } \\
\cline { 3 - 4 } & & \multicolumn{1}{|c|}{1998} & 2001 \\
\hline All & All children in survey & 21733 & 26429 \\
\hline Step 1 & Restricted to mainland Portugal & 21733 & 24382 \\
\hline Step 2 & Restricted to age group 6 to 12 in 1998 and 9 to 15 in 2001 & 13623 & 18536 \\
\hline Step 3 & $\begin{array}{l}\text { Restricted the 2001 sample to those living in the same } \\
\text { residence for at least three years }\end{array}$ & 13623 & 17575 \\
\hline Step 4 & $\begin{array}{l}\text { Matching children on the basis of municipality, number of } \\
\text { rooms in the house, child age and sex, age of mother and } \\
\text { father and schooling of mother and father }\end{array}$ & 1821 & 1821 \\
\hline Step 5 & Observations available for all relevant variables & 1733 & 1682 \\
\hline
\end{tabular}


Table 3

Comparison of descriptive statistics for cross-section and panel data

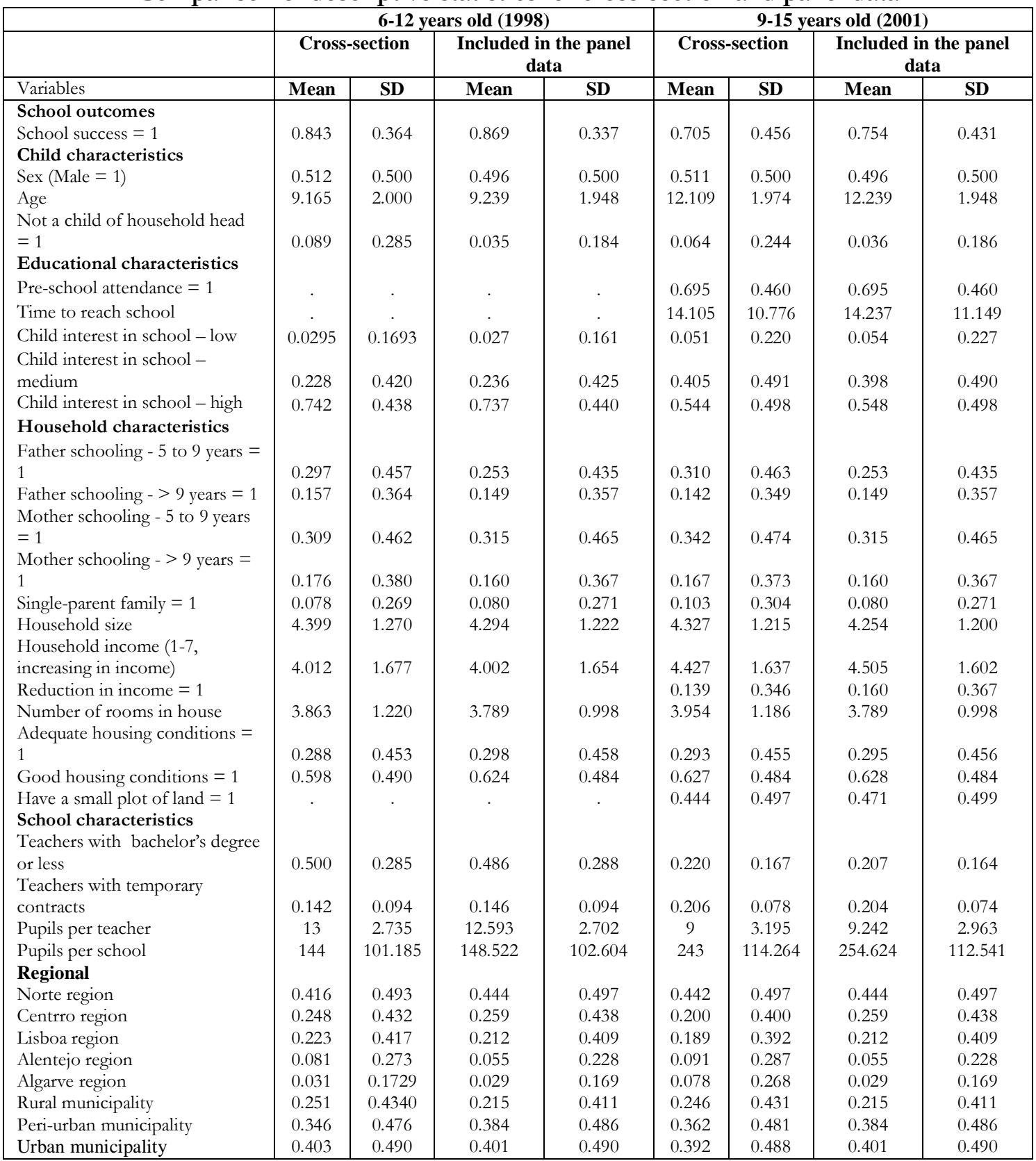

Notes: In 1998, $N=13,623$, with the exception of the school characteristics variables where $N=13,583$. In the 2001 survey, $N=18,536$ with the exception of interest and achievement $(\mathrm{N}=18,531)$, time to school $(\mathrm{N}=18,212)$ and school characteristics $(\mathrm{N}=18,163)$. For the panel data, in 1998, $\mathrm{N}=1733$, except for the school characteristics where $\mathrm{N}=1730$; in 2001, $\mathrm{N}=1733$, except for school success and time to school where $\mathrm{N}=1690$ and school characteristics where $\mathrm{N}=1682$. 
Table 4

Age and school success

\begin{tabular}{|c|c|c|}
\hline Age & $\begin{array}{c}\text { School success }(\%) \\
1998\end{array}$ & $\begin{array}{c}\text { School success }(\%) \\
2001\end{array}$ \\
\hline 6 & 99.24 & 99.15 \\
7 & 96.05 & 94.81 \\
8 & 87.81 & 87.03 \\
9 & 84.68 & 84.18 \\
10 & 80.38 & 77.18 \\
11 & 75.94 & 74.59 \\
12 & 71.43 & 71.52 \\
13 & 65.77 & 65.01 \\
14 & 59.62 & 59.85 \\
15 & 54.38 & 54.03 \\
\hline Overall & 74.99 & 74.78 \\
\hline
\end{tabular}

Notes: $N=21,729$ for 1998 and 26,392 for 2001 .

Success is defined as "never repeated a grade".

Table 5

Child interest in school

\begin{tabular}{|l|c|c|c|}
\hline & $\begin{array}{c}\text { Child's response } \\
\mathbf{1 9 9 8}\end{array}$ & $\begin{array}{c}\text { Child's response } \\
\mathbf{2 0 0 1}\end{array}$ & $\begin{array}{c}\text { Parent's response } \\
\mathbf{2 0 0 1}\end{array}$ \\
\hline Low interest (\%) & 5.3 & 4.6 & 6.9 \\
Medium interest (\%) & 28.1 & 36.9 & 37.5 \\
Very interested (\%) & 66.6 & 58.5 & 55.5 \\
\hline \multicolumn{1}{|c|}{$N$} & 21,729 & 26,392 & 26,392 \\
\hline
\end{tabular}

Table 6

Comparing parent and child responses to child interest in school, 2001

(percent)

\begin{tabular}{|l|ccc|l|}
\hline & \multicolumn{3}{|c|}{ Child's response } & \\
\hline Parental response & Low interest & Medium interest & Very interested & Total \\
\hline Low interest (\%) & 2.1 & 3.4 & 1.5 & 6.9 \\
Medium interest (\%) & 1.8 & 20.2 & 15.5 & 37.5 \\
Very interested (\%) & 0.7 & 13.3 & 41.6 & 55.5 \\
\hline Total & 4.6 & 36.9 & 58.5 & 100.0 \\
\hline
\end{tabular}

$N=26,392$. 
Table 7a

Age and child interest, 1998

\begin{tabular}{|c|c|c|c|}
\hline Age & Low $(\%)$ & Medium $(\%)$ & High (\%) \\
\hline 6 & 0.9 & 11.31 & 87.81 \\
7 & 2.05 & 18.06 & 79.87 \\
8 & 2.16 & 19.22 & 78.61 \\
9 & 2.58 & 22.19 & 75.22 \\
10 & 3.29 & 23.96 & 72.75 \\
11 & 4.67 & 30.03 & 65.28 \\
12 & 4.91 & 31.22 & 63.85 \\
13 & 6.05 & 35.26 & 58.71 \\
14 & 8.87 & 38.65 & 52.46 \\
15 & 11.58 & 36.67 & 51.80 \\
\hline \multicolumn{3}{|c|}{$N=21.729$} \\
\hline
\end{tabular}

Table $7 \mathrm{~b}$

Age and child interest, 2001 (child response)

\begin{tabular}{|c|c|c|c|}
\hline Age & Low $(\%)$ & Medium $(\%)$ & High $(\%)$ \\
\hline 6 & 1.12 & 20.92 & 77.88 \\
7 & 1.98 & 23.01 & 75.0 \\
8 & 2.74 & 28.55 & 68.69 \\
9 & 2.26 & 31.08 & 66.65 \\
10 & 2.63 & 32.27 & 65.09 \\
11 & 3.29 & 37.58 & 59.11 \\
12 & 4.44 & 42.32 & 53.23 \\
13 & 5.72 & 45.03 & 49.24 \\
14 & 7.44 & 48.17 & 44.37 \\
15 & 11.0 & 46.54 & 42.41 \\
\hline \multicolumn{3}{|c|}{$N=26,392$} \\
\hline
\end{tabular}

Table 7c

Age and child interest, 2001 (parental response)

\begin{tabular}{|c|c|c|c|}
\hline Age & Low $(\%)$ & Medium $(\%)$ & High (\%) \\
\hline 6 & 0.88 & 27.66 & 71.44 \\
7 & 2.03 & 32.55 & 65.41 \\
8 & 3.34 & 34.30 & 62.34 \\
9 & 3.85 & 35.96 & 60.17 \\
10 & 5.19 & 36.99 & 57.81 \\
11 & 5.07 & 39.14 & 55.78 \\
12 & 6.30 & 40.39 & 53.30 \\
13 & 8.47 & 40.96 & 50.56 \\
14 & 11.92 & 41.47 & 46.60 \\
15 & 17.12 & 39.87 & 43.00 \\
\hline \multicolumn{3}{|c|}{$N=26,392$} \\
\hline
\end{tabular}


Table 8

School success and interest

\begin{tabular}{|c|c|c|c|}
\hline & \multicolumn{3}{|c|}{ Interest } \\
\hline & Low & Medium & High \\
\hline 1998 & & & \\
\hline Success $(\%)$ & 25.5 & 59.8 & 85.3 \\
\hline$N$ & 1,152 & 6,098 & 14,479 \\
\hline Correlation & & 0.375 & \\
\hline$(\mathrm{p}$-value $)$ & & $(0.000)$ & \\
\hline 2001 (child response) & & & \\
\hline Success $(\%)$ & 26.6 & 63.9 & 85.4 \\
\hline$N$ & 1,209 & 9,735 & 15,448 \\
\hline Correlation & & 0.333 & \\
\hline (p-value) & & $(0.000)$ & \\
\hline 2001 (parental response) & & & \\
\hline Success $(\%)$ & 11.7 & 65.3 & 89.02 \\
\hline$N$ & 1,830 & 9,906 & 14,656 \\
\hline Correlation & & 0.454 & \\
\hline (p-value) & & $(0.000)$ & \\
\hline
\end{tabular}

Note: Success is defined as "never repeated a grade".

Table 9

Age, school success and interest

\begin{tabular}{|c|c|c|c|c|c|c|c|c|}
\hline & \multicolumn{4}{|c|}{ School success (\%) } & \multicolumn{4}{c|}{ School success (\%) } \\
\hline & \multicolumn{3}{|c|}{1998} & \multicolumn{3}{c|}{} \\
\hline Age & Low & Medium & High & Correlation & Low & Medium & High & Correlation \\
\hline 6 & 86.66 & 96.92 & 99.66 & 0.153 & 95.8 & 98.6 & 99.3 & 0.049 \\
7 & 78.37 & 88.92 & 98.12 & 0.224 & 69.2 & 89.8 & 97.0 & 0.200 \\
8 & 57.50 & 76.61 & 91.39 & 0.224 & 37.5 & 80.0 & 91.9 & 0.266 \\
9 & 30.61 & 73.80 & 89.74 & 0.289 & 45.6 & 77.1 & 88.7 & 0.206 \\
10 & 30.88 & 66.73 & 87.11 & 0.312 & 36.9 & 64.9 & 84.8 & 0.269 \\
11 & 25.77 & 67.09 & 83.60 & 0.298 & 32.9 & 67.3 & 81.5 & 0.225 \\
12 & 27.52 & 58.52 & 81.13 & 0.317 & 29.4 & 64.4 & 80.6 & 0.256 \\
13 & 22.14 & 55.17 & 76.59 & 0.311 & 18.6 & 56.4 & 78.2 & 0.319 \\
14 & 17.67 & 48.61 & 74.83 & 0.366 & 25.9 & 51.4 & 74.6 & 0.299 \\
15 & 18.08 & 41.86 & 71.28 & 0.378 & 10.1 & 46.5 & 73.6 & 0.399 \\
\hline
\end{tabular}

Notes: $N=21,729$ for 1998 and 26,392 for 2001. Success is defined as "never repeated a grade". The column "Correlation", indicates age-specific correlation between school success and interest. 
Table 10

Probability of school success, 1998

\begin{tabular}{|c|c|c|c|c|}
\hline $\begin{array}{l}\text { Specifications } \\
\text { VARIABLES }\end{array}$ & (1) & (2) & (3) & (4) \\
\hline \multicolumn{5}{|l|}{ Child characteristics } \\
\hline Interest in school - medium & $\begin{array}{l}0.23^{* * *} \\
(0.010)\end{array}$ & $\begin{array}{l}0.20^{* * *} \\
(0.0095)\end{array}$ & $\begin{array}{l}0.15^{* * *} \\
(0.0094)\end{array}$ & $\begin{array}{l}0.12^{* * *} \\
(0.0100)\end{array}$ \\
\hline Interest in school - high & $\begin{array}{l}0.56^{* * *} \\
(0.014)\end{array}$ & $\begin{array}{l}0.48^{* * *} \\
(0.016)\end{array}$ & $\begin{array}{l}0.39 * * * \\
(0.016)\end{array}$ & $\begin{array}{l}0.33^{* * *} \\
(0.018)\end{array}$ \\
\hline Sex $($ male $=1)$ & & $\begin{array}{l}-0.051 * * * \\
(0.0057)\end{array}$ & $\begin{array}{l}-0.058^{* * *} \\
(0.0054)\end{array}$ & $\begin{array}{l}-0.049 * * * \\
(0.0053)\end{array}$ \\
\hline Age & & $\begin{array}{l}-0.14 * * * \\
(0.010)\end{array}$ & $\begin{array}{l}-0.13 * * * \\
(0.0096)\end{array}$ & $\begin{array}{l}-0.19 * * * \\
(0.012)\end{array}$ \\
\hline \multicolumn{5}{|l|}{ Family/socio-economic characteristics } \\
\hline Head of household's schooling 5-9 years & & & $\begin{array}{l}0.061 * * * \\
(0.0058)\end{array}$ & $\begin{array}{l}0.053 * * * \\
(0.0057)\end{array}$ \\
\hline Head of household's schooling $>9$ years & & & $\begin{array}{l}0.13 * * * \\
(0.0066)\end{array}$ & $\begin{array}{l}0.12 * * * \\
(0.0062)\end{array}$ \\
\hline Single parent family & & & $\begin{array}{l}-0.064 * * * \\
(0.011)\end{array}$ & $\begin{array}{l}-0.054^{* * *} \\
(0.011)\end{array}$ \\
\hline Household size & & & $\begin{array}{l}-0.031 * * * \\
(0.0022)\end{array}$ & $\begin{array}{l}-0.024 * * * \\
(0.0023)\end{array}$ \\
\hline Household income & & & $\begin{array}{l}0.024 * * * \\
(0.0020)\end{array}$ & $\begin{array}{l}0.019 * * * \\
(0.0020)\end{array}$ \\
\hline Number of rooms in house & & & $\begin{array}{l}0.020 * * * \\
(0.0025)\end{array}$ & $\begin{array}{l}0.018 * * * \\
(0.0026)\end{array}$ \\
\hline Adequate housing conditions & & & $\begin{array}{l}0.064 * * * \\
(0.0079)\end{array}$ & $\begin{array}{l}0.047 * * * \\
(0.0080)\end{array}$ \\
\hline Good housing conditions & & & $\begin{array}{l}0.11 * * * \\
(0.0097)\end{array}$ & $\begin{array}{l}0.083 * * * \\
(0.0096)\end{array}$ \\
\hline Educational inputs & & & & \\
\hline Teachers with bachelor's degree or less & & & & $\begin{array}{l}-0.015 \\
(0.038)\end{array}$ \\
\hline Teachers with temporary contracts & & & & $\begin{array}{l}0.29 * * * \\
(0.068)\end{array}$ \\
\hline Pupil-teacher ratio & & & & $\begin{array}{l}-0.013^{* * *} \\
(0.0024)\end{array}$ \\
\hline Pupils per school & & & & $\begin{array}{l}0.0013^{* * *} \\
(0.000048)\end{array}$ \\
\hline Observations & 21,318 & 21,318 & 21,308 & 21,267 \\
\hline Log likelihood & -10522 & -9580 & -8663 & $-7,641$ \\
\hline Pseudo R2 & 0.109 & 0.188 & 0.2659 & 0.3514 \\
\hline
\end{tabular}

Notes: Other variables included in the specification are age-squared, an indicator if the child is not the son of the head of the household and another if the household owns a plot, a set of regional indicators for the province of residence, indicators for residing in urban, semi-rural and rural areas. Table provides probit marginal effects with robust standard errors in parentheses, ${ }^{* * *} \mathrm{p}<0.01,{ }^{* *} \mathrm{p}<0.05,{ }^{*} \mathrm{p}<0.1$. 
Table 11

Probability of school success, 2001

\begin{tabular}{|c|c|c|c|c|c|}
\hline $\begin{array}{l}\text { Specifications } \\
\text { VARIABLES }\end{array}$ & (1) & (2) & (3) & $\begin{array}{c}(4) \\
\text { Child } \\
\text { response }\end{array}$ & $\begin{array}{c}\text { (5) } \\
\text { Parents } \\
\text { response }\end{array}$ \\
\hline \multicolumn{6}{|l|}{ Child characteristics } \\
\hline Interest in school - medium & $\begin{array}{l}0.27 * * * \\
(0.010)\end{array}$ & $\begin{array}{l}0.21 \text { *** } \\
(0.010)\end{array}$ & $\begin{array}{l}0.16 * * * \\
(0.010)\end{array}$ & $\begin{array}{l}0.12^{* * *} \\
(0.010)\end{array}$ & $\begin{array}{l}0.25^{* * *} \\
(0.011)\end{array}$ \\
\hline Interest in school - good & $\begin{array}{l}0.53 * * * \\
(0.012)\end{array}$ & $\begin{array}{l}0.40^{* * *} \\
(0.013)\end{array}$ & $\begin{array}{l}0.32 * * * \\
(0.014)\end{array}$ & $\begin{array}{l}0.25^{* * *} \\
(0.015)\end{array}$ & $\begin{array}{l}0.50 * * * \\
(0.016)\end{array}$ \\
\hline Sex $($ male $=1)$ & & $\begin{array}{l}-0.074 * * * \\
(0.0052)\end{array}$ & $\begin{array}{l}-0.081 * * * \\
(0.0050)\end{array}$ & $\begin{array}{l}-0.066^{* * *} \\
(0.0047)\end{array}$ & $\begin{array}{l}-0.052^{* * *} \\
(0.0048)\end{array}$ \\
\hline Age & & $\begin{array}{l}-0.15^{* * *} \\
(0.0085)\end{array}$ & $\begin{array}{l}-0.15^{* * *} \\
(0.0083)\end{array}$ & $\begin{array}{l}-0.22 * * * \\
(0.012)\end{array}$ & $\begin{array}{l}-0.22^{* * *} \\
(0.012)\end{array}$ \\
\hline Pre-school attendance & & $\begin{array}{l}0.080 * * * \\
(0.0062)\end{array}$ & $\begin{array}{l}0.014 * * \\
(0.0056)\end{array}$ & $\begin{array}{l}0.021 * * * \\
(0.0055)\end{array}$ & $\begin{array}{l}0.023 * * * \\
(0.0056)\end{array}$ \\
\hline Time to school (minutes) & & $\begin{array}{l}-0.00072^{* * *} \\
(0.00025)\end{array}$ & $\begin{array}{l}0.00028 \\
(0.00024)\end{array}$ & $\begin{array}{l}-0.00076^{* * *} \\
(0.00023)\end{array}$ & $\begin{array}{l}-0.00068^{* * *} \\
(0.00023)\end{array}$ \\
\hline \multicolumn{6}{|l|}{ Family/socio-economic characteristics } \\
\hline Head of household's schooling 5-9 years & & & $\begin{array}{l}0.098^{* * *} * \\
(0.0053)\end{array}$ & $\begin{array}{l}0.082^{* * *} \\
(0.0051)\end{array}$ & $\begin{array}{l}0.071^{* * *} \\
(0.0052)\end{array}$ \\
\hline Head of household's schooling $>9$ years & & & $\begin{array}{l}0.16 * * * \\
(0.0059)\end{array}$ & $\begin{array}{l}0.13^{* * *} \\
(0.0051)\end{array}$ & $\begin{array}{l}0.11^{* * *} \\
(0.0058)\end{array}$ \\
\hline Single parent family & & & $\begin{array}{l}-0.065^{* * *} \\
(0.0099)\end{array}$ & $\begin{array}{l}-0.047 * * * \\
(0.0097)\end{array}$ & $\begin{array}{l}-0.039 * * * \\
(0.0097)\end{array}$ \\
\hline Household size & & & $\begin{array}{l}-0.040 * * * \\
(0.0020)\end{array}$ & $\begin{array}{l}-0.026^{* * *} \\
(0.0021)\end{array}$ & $\begin{array}{l}-0.024 * * * \\
(0.0021)\end{array}$ \\
\hline Household income & & & $\begin{array}{l}0.031 * * * \\
(0.0018)\end{array}$ & $\begin{array}{l}0.020 * * * \\
(0.0018)\end{array}$ & $\begin{array}{l}0.021 * * * \\
(0.0018)\end{array}$ \\
\hline Reduction in income $=1$ & & & $\begin{array}{l}-0.022 * * * \\
(0.0073)\end{array}$ & $\begin{array}{l}-0.013^{*} \\
(0.0068)\end{array}$ & $\begin{array}{l}-0.0051 \\
(0.0068)\end{array}$ \\
\hline Number of rooms in house & & & $\begin{array}{l}0.020^{* * *} \\
(0.0025)\end{array}$ & $\begin{array}{l}0.020^{* * *} \\
(0.0024)\end{array}$ & $\begin{array}{l}0.018^{* * *} \\
(0.0024)\end{array}$ \\
\hline Adequate housing conditions & & & $\begin{array}{l}0.055^{* * *} \\
(0.0082)\end{array}$ & $\begin{array}{l}0.042^{* * *} \\
(0.0079)\end{array}$ & $\begin{array}{l}0.031^{* * *} \\
(0.0083)\end{array}$ \\
\hline Good housing conditions & & & $\begin{array}{l}0.093 * * * \\
(0.0098)\end{array}$ & $\begin{array}{l}0.074 * * * \\
(0.0096)\end{array}$ & $\begin{array}{l}0.050^{* * *} \\
(0.0096)\end{array}$ \\
\hline Family has a plot $=1$ & & & $\begin{array}{l}0.0097 * \\
(0.0052)\end{array}$ & $\begin{array}{l}0.0019 \\
(0.0051)\end{array}$ & $\begin{array}{l}0.0080 \\
(0.0051)\end{array}$ \\
\hline Educational inputs & & & & & \\
\hline Teachers with bachelors degree or less & & & & $\begin{array}{l}-0.11 * * * \\
(0.041)\end{array}$ & $\begin{array}{l}-0.12 * * * \\
(0.042)\end{array}$ \\
\hline Teachers with temporary contracts & & & & $\begin{array}{l}12.6^{* *} \\
(5.03)\end{array}$ & $\begin{array}{l}8.19 \\
(5.12)\end{array}$ \\
\hline Pupil-teacher ratio & & & & $\begin{array}{l}-0.0076^{* * *} \\
(0.0014)\end{array}$ & $\begin{array}{l}-0.0070^{* * *} \\
(0.0014)\end{array}$ \\
\hline Pupils per school & & & & $\begin{array}{l}0.0015^{* * *} \\
(0.000051)\end{array}$ & $\begin{array}{l}0.0013^{* * *} \\
(0.000051)\end{array}$ \\
\hline Observations & 26,045 & 26,045 & 26,027 & 23,959 & 23,959 \\
\hline Log Likelihood & $-13,484$ & $-12,101$ & $-10,787$ & $-8,470$ & -7680 \\
\hline Pseudo R2 & 0.095 & 0.166 & 0.256 & 0.347 & 0.408 \\
\hline
\end{tabular}

Notes: Other variables included in the specification are age-squared, an indicator if the child is not the son of the head of the household and another if the household owns a plot, a set of regional indicators for the province of residence, indicators for residing in urban, semi-rural and rural areas. Table provides probit marginal effects with robust standard errors in parentheses, ${ }^{* * *} \mathrm{p}<0.01,{ }^{* *} \mathrm{p}<0.05,{ }^{*} \mathrm{p}<0.1$ 
Table 12

School Success and Interest-Panel data

\begin{tabular}{|c|c|c|c|c|}
\hline Year & $\begin{array}{c}\text { School success } \\
\mathbf{\%}\end{array}$ & $\begin{array}{c}\text { Low } \\
\mathbf{\%}\end{array}$ & $\begin{array}{c}\text { Medium } \\
\mathbf{\%}\end{array}$ & $\begin{array}{c}\text { High } \\
\mathbf{\%}\end{array}$ \\
\hline 1998 & 86.8 & 2.7 & 23.6 & 73.7 \\
\hline 2001 & 74.6 & 5.5 & 39.7 & 54.8 \\
\hline
\end{tabular}

Notes: $\mathrm{N}=1733$

Table 13

School success - 1998 and 2001

\begin{tabular}{|c|c|c|c|}
\hline School Success & \multicolumn{3}{|c|}{ School Success 2001 } \\
\hline School Success, 1998 & 0 & 1 & Total \\
\hline 0 & 212 & 16 & 228 \\
& 12.2 & 0.92 & 13.2 \\
\hline 1 & 228 & 1277 & 865 \\
& 13.1 & 73.7 & 1733 \\
\hline Total & 440 & 1293 & 100 \\
\hline
\end{tabular}

Notes: $\mathrm{N}=1733$

Table 14

Child interest in school - 1998 and 2001

\begin{tabular}{|l|ccc|c|}
\hline \multicolumn{1}{|c|}{$\mathbf{1 9 9 8}$} & Low interest & Medium interest & Very interested & Total \\
\hline Low interest (\%) & 0.52 & 1.5 & 0.63 & 2.7 \\
Medium interest (\%) & 2.3 & 10.7 & 10.6 & 23.6 \\
Very interested (\%) & 2.6 & 27.5 & 43.6 & 73.7 \\
\hline Total & 5.5 & 39.7 & 54.8 & 100.0 \\
\hline
\end{tabular}

Notes: $N=1733$ 
Table 15

Probability of school success - Panel data estimates

\begin{tabular}{|c|c|c|c|}
\hline $\begin{array}{l}\text { Specifications } \\
\text { VARIABLES }\end{array}$ & $\begin{array}{c}(1) \\
\text { Pooled OLS }\end{array}$ & $\begin{array}{c}(2) \\
\text { Differenced } \\
\text { regression }\end{array}$ & $\begin{array}{c}(3) \\
\text { Differenced } \\
\text { regression }\end{array}$ \\
\hline Timing of interest variable & Contemporaneous & Contemporaneous & Lagged \\
\hline \multicolumn{4}{|l|}{ Child characteristics } \\
\hline Interest in school - medium & $\begin{array}{c}0.13 * * * \\
(0.020)\end{array}$ & $\begin{array}{c}0.16^{* * *} \\
(0.043)\end{array}$ & $\begin{array}{l}-0.026 \\
(0.057)\end{array}$ \\
\hline Interest in school - high & $\begin{array}{l}0.28^{* * *} \\
(0.040)\end{array}$ & $\begin{array}{l}0.18^{* * *} \\
(0.043)\end{array}$ & $\begin{array}{c}0.036 \\
(0.055)\end{array}$ \\
\hline \multicolumn{4}{|l|}{ Family/socio-economic characteristics } \\
\hline Household size & $\begin{array}{c}-0.017 * * * \\
(0.0046)\end{array}$ & $\begin{array}{r}-0.0091 \\
(0.014)\end{array}$ & $\begin{array}{c}-0.0091 \\
(0.015)\end{array}$ \\
\hline Household income & $\begin{array}{l}0.025 * * * \\
(0.0036)\end{array}$ & $\begin{array}{l}-0.0072 \\
(0.0069)\end{array}$ & $\begin{array}{l}-0.0069 \\
(0.0070)\end{array}$ \\
\hline Adequate housing conditions & $\begin{array}{l}0.034^{*} \\
(0.019)\end{array}$ & $\begin{array}{c}0.044 \\
(0.036)\end{array}$ & $\begin{array}{l}0.046 \\
(0.037)\end{array}$ \\
\hline Good housing conditions & $\begin{array}{c}0.088^{* * *} \\
(0.024)\end{array}$ & $\begin{array}{c}0.028 \\
(0.038)\end{array}$ & $\begin{array}{c}0.034 \\
(0.039)\end{array}$ \\
\hline \multicolumn{4}{|l|}{ Educational inputs } \\
\hline Teacher with bachelor's degree or less & $\begin{array}{l}-0.028 \\
(0.074)\end{array}$ & $\begin{array}{c}0.13 \\
(0.089)\end{array}$ & $\begin{array}{c}0.12 \\
(0.090)\end{array}$ \\
\hline Teacher with temporary contracts & $\begin{array}{c}0.11 \\
(0.15)\end{array}$ & $\begin{array}{l}0.053 \\
(0.18)\end{array}$ & $\begin{array}{l}0.013 \\
(0.18)\end{array}$ \\
\hline Pupil-teacher ratio & $\begin{array}{c}-0.018^{* * *} \\
(0.0034)\end{array}$ & $\begin{array}{c}-0.0082 * \\
(0.0042)\end{array}$ & $\begin{array}{c}-0.0085^{* *} \\
(0.0043)\end{array}$ \\
\hline Pupils per school & $\begin{array}{l}0.0011 * * * \\
(0.000096)\end{array}$ & $\begin{array}{c}0.00089 * * * \\
(0.00013)\end{array}$ & $\begin{array}{c}0.00091 * * * \\
(0.00013)\end{array}$ \\
\hline Year $=2001$ & $\begin{array}{l}0.0052 \\
(0.032)\end{array}$ & $\begin{array}{c}-0.20^{* * *} \\
(0.040)\end{array}$ & $\begin{array}{c}-0.24 * * * \\
(0.068)\end{array}$ \\
\hline $\begin{array}{l}\text { Observations } \\
\text { R-squared/Pseudo R² }\end{array}$ & $\begin{array}{l}3412 \\
0.286\end{array}$ & $\begin{array}{l}1,666 \\
0.071\end{array}$ & $\begin{array}{l}1,666 \\
0.060\end{array}$ \\
\hline
\end{tabular}

Robust standard errors in parentheses *** $\mathrm{p}<0.01,{ }^{* *} \mathrm{p}<0.05, * \mathrm{p}<0.1$ 
Table A1

Probability of school success, 1998 and 2001

\begin{tabular}{|c|c|c|c|c|}
\hline \multirow{2}{*}{$\begin{array}{l}\text { VARIABLES } \\
\text { Child characteristics }\end{array}$} & $(1)$ & $(2)$ & (3) & $(4)$ \\
\hline & $\begin{array}{c}\text { Full } \\
\text { sample } \\
1998 \\
(6-12)\end{array}$ & $\begin{array}{c}\text { Panel } \\
\text { sample } \\
1998 \\
(6-12)\end{array}$ & $\begin{array}{c}\text { Full } \\
\text { sample } \\
2001 \\
(9-15)\end{array}$ & $\begin{array}{c}\text { Panel } \\
\text { sample } \\
2001 \\
(6-12)\end{array}$ \\
\hline Interest in school - medium & $\begin{array}{l}0.067 * * * \\
(0.0072)\end{array}$ & $\begin{array}{c}0.071 * * * \\
(0.018)\end{array}$ & $\begin{array}{c}0.15^{* * *} \\
(0.016)\end{array}$ & $\begin{array}{c}0.19 * * * \\
(0.044)\end{array}$ \\
\hline Interest in school - high & $\begin{array}{l}0.24 * * * \\
(0.022)\end{array}$ & $\begin{array}{l}0.24 * * * \\
(0.064)\end{array}$ & $\begin{array}{c}0.28^{* * *} \\
(0.018)\end{array}$ & $\begin{array}{l}0.28 * * * \\
(0.056)\end{array}$ \\
\hline Sex $($ male $=1)$ & $\begin{array}{c}-0.025^{* * *} \\
(0.0045)\end{array}$ & $\begin{array}{l}-0.022^{*} \\
(0.011)\end{array}$ & $\begin{array}{c}-0.095^{* * *} \\
(0.0067)\end{array}$ & $\begin{array}{c}-0.075^{* * *} \\
(0.020)\end{array}$ \\
\hline Age & $\begin{array}{l}-0.023 \\
(0.015)\end{array}$ & $\begin{array}{c}0.022 \\
(0.041)\end{array}$ & $\begin{array}{c}-0.59 * * * \\
(0.037)\end{array}$ & $\begin{array}{c}-0.46^{* * *} \\
(0.12)\end{array}$ \\
\hline Pre-school attendance & & & $\begin{array}{l}0.025^{* * *} \\
(0.0077)\end{array}$ & $\begin{array}{c}0.012 \\
(0.022)\end{array}$ \\
\hline Time to school & & & $\begin{array}{c}-0.0010^{* * *} \\
(0.00032)\end{array}$ & $\begin{array}{l}0.000090 \\
(0.00089)\end{array}$ \\
\hline \multicolumn{5}{|l|}{$\begin{array}{l}\text { Family/socio-economic } \\
\text { characteristics }\end{array}$} \\
\hline \multirow[t]{2}{*}{$\begin{array}{l}\text { Head of household's schooling 5-9 } \\
\text { years }\end{array}$} & $0.037 * * *$ & $0.028^{* *}$ & $0.11 * * *$ & $0.11 * * *$ \\
\hline & $(0.0046)$ & $(0.012)$ & $(0.0072)$ & $(0.019)$ \\
\hline \multirow[t]{2}{*}{$\begin{array}{l}\text { Head of household's schooling }>9 \\
\text { years }\end{array}$} & $0.072^{* * *}$ & $0.056^{* * *}$ & $0.19 * * *$ & $0.16^{* * *}$ \\
\hline & $(0.0048)$ & $(0.013)$ & $(0.0079)$ & $(0.022)$ \\
\hline Single parent family & $\begin{array}{c}-0.029 * * * \\
(0.010)\end{array}$ & $\begin{array}{c}-0.063 * * \\
(0.030)\end{array}$ & $\begin{array}{c}-0.076^{* * *} \\
(0.014)\end{array}$ & $\begin{array}{l}-0.10^{* *} \\
(0.050)\end{array}$ \\
\hline Household size & $\begin{array}{c}-0.015^{* * *} \\
(0.0018)\end{array}$ & $\begin{array}{c}-0.014 * * * \\
(0.0047)\end{array}$ & $\begin{array}{l}-0.033 * * * \\
(0.0032)\end{array}$ & $\begin{array}{l}-0.020 * * \\
(0.0092)\end{array}$ \\
\hline Household income & $\begin{array}{l}0.012^{* * *} \\
(0.0017)\end{array}$ & $\begin{array}{l}0.0038 \\
(0.0045)\end{array}$ & $\begin{array}{l}0.027 * * * \\
(0.0025)\end{array}$ & $\begin{array}{c}0.011 \\
(0.0076)\end{array}$ \\
\hline Reduction in income & & & $\begin{array}{l}-0.022 * * \\
(0.0099)\end{array}$ & $\begin{array}{l}-0.048 \\
(0.030)\end{array}$ \\
\hline Number of rooms in house & $\begin{array}{l}0.011 * * * \\
(0.0023)\end{array}$ & $\begin{array}{l}0.016^{* *} \\
(0.0070)\end{array}$ & $\begin{array}{l}0.026^{* * *} \\
(0.0035)\end{array}$ & $\begin{array}{c}0.051 * * * \\
(0.013)\end{array}$ \\
\hline Adequate housing conditions & $\begin{array}{c}0.024 * * * \\
(0.0061)\end{array}$ & $\begin{array}{c}0.010 \\
(0.019)\end{array}$ & $\begin{array}{c}0.062^{* * *} \\
(0.012)\end{array}$ & $\begin{array}{c}-0.0054 \\
(0.040)\end{array}$ \\
\hline Good housing conditions & $\begin{array}{c}0.055^{* * *} \\
(0.0081)\end{array}$ & $\begin{array}{c}0.019 \\
(0.022)\end{array}$ & $\begin{array}{c}0.10^{* * *} \\
(0.014)\end{array}$ & $\begin{array}{c}0.042 \\
(0.041)\end{array}$ \\
\hline Have a plot & & & $\begin{array}{l}0.00079 \\
(0.0074)\end{array}$ & $\begin{array}{l}-0.019 \\
(0.023)\end{array}$ \\
\hline \multicolumn{5}{|l|}{ Educational inputs } \\
\hline Teachers with bachelor's degree or less & $\begin{array}{l}-0.013 \\
(0.032)\end{array}$ & $\begin{array}{c}0.026 \\
(0.084)\end{array}$ & $\begin{array}{c}-0.41 * * * \\
(0.066)\end{array}$ & $\begin{array}{c}-0.54^{* *} \\
(0.21)\end{array}$ \\
\hline Teachers with temporary contracts & $\begin{array}{c}0.26 \text { *** } \\
(0.064)\end{array}$ & $\begin{array}{l}0.058 \\
(0.17)\end{array}$ & $\begin{array}{l}12.3^{*} \\
(7.07)\end{array}$ & $\begin{array}{l}-29.3 \\
(20.3)\end{array}$ \\
\hline Pupil-teacher ratio & $\begin{array}{c}-0.0080^{* * *} * \\
(0.0017)\end{array}$ & $\begin{array}{c}-0.013 * * * \\
(0.0051)\end{array}$ & $\begin{array}{c}-0.010^{* * *} \\
(0.0023)\end{array}$ & $\begin{array}{l}-0.0032 \\
(0.0075)\end{array}$ \\
\hline Pupils per school & $\begin{array}{l}0.00095^{* * *} \\
(0.000054)\end{array}$ & $\begin{array}{c}0.00095^{* * *} \\
(0.00014)\end{array}$ & $\begin{array}{l}0.0020 * * * \\
(0.000066)\end{array}$ & $\begin{array}{l}0.0017 * * * \\
(0.00019)\end{array}$ \\
\hline Observations & 13575 & 1730 & 18150 & 1682 \\
\hline Log likelihood & -3748 & -447 & -7385 & -633 \\
\hline Pseudo R2 & 0.364 & 0.334 & 0.321 & 0.3241 \\
\hline
\end{tabular}

Notes: Other variables included in the specification are age-squared, an indicator if the child is not the son of the head of the household, a set of regional indicators for the province of residence, indicators for residing in urban, semi-rural and rural areas. Table provides probit marginal effects with robust standard errors in parentheses, ${ }^{* * *} \mathrm{p}<0.01,{ }^{* *} \mathrm{p}<0.05,{ }^{*} \mathrm{p}<0.1$. 
Table A2

Probability of school success - lagged interest

\begin{tabular}{|c|c|c|c|}
\hline VARIABLES & $\begin{array}{l}\text { (1) } \\
\text { OLS }\end{array}$ & $\begin{array}{c}(2) \\
\text { OLS }\end{array}$ & $\begin{array}{c}\text { (3) } \\
\text { OLS }\end{array}$ \\
\hline \multicolumn{4}{|l|}{ Child characteristics } \\
\hline Interest in school in 1998 - medium & $\begin{array}{c}0.30^{* * *} \\
(0.077)\end{array}$ & $\begin{array}{c}0.28^{* * *} \\
(0.074)\end{array}$ & $\begin{array}{c}0.28^{* * *} \\
(0.073)\end{array}$ \\
\hline Interest in school in 1998 - high & $\begin{array}{c}0.49 * * * \\
(0.074)\end{array}$ & $\begin{array}{c}0.46^{* * *} \\
(0.071)\end{array}$ & $\begin{array}{c}0.47 * * * \\
(0.069)\end{array}$ \\
\hline \multicolumn{4}{|c|}{ Family/socio-economic characteristics } \\
\hline Household size & & $\begin{array}{c}-0.035^{* * *} \\
(0.0096)\end{array}$ & $\begin{array}{c}-0.030 * * * \\
(0.0096)\end{array}$ \\
\hline Household income & . & $\begin{array}{c}0.053 * * * \\
(0.0061)\end{array}$ & $\begin{array}{c}0.051 * * * \\
(0.0063)\end{array}$ \\
\hline Adequate housing conditions & & $\begin{array}{c}0.17 * * * \\
(0.050)\end{array}$ & $\begin{array}{c}0.15^{* * *} \\
(0.051)\end{array}$ \\
\hline Good housing conditions & & $\begin{array}{c}0.24 * * * \\
(0.049)\end{array}$ & $\begin{array}{c}0.23^{* * *} \\
(0.049)\end{array}$ \\
\hline \multicolumn{4}{|l|}{ Educational inputs } \\
\hline Teachers with bachelor's degree or less & & & $\begin{array}{c}0.0097 \\
(0.15)\end{array}$ \\
\hline Teachers with temporary contracts & . & & $\begin{array}{l}-16.9 \\
(19.5)\end{array}$ \\
\hline Pupil-teacher ratio & & & $\begin{array}{l}-0.0058 \\
(0.0060)\end{array}$ \\
\hline Pupils per school & & & $\begin{array}{c}0.00045^{* * *} \\
(0.00012)\end{array}$ \\
\hline Constant & $\begin{array}{c}0.32^{* * *} \\
(0.073)\end{array}$ & $\begin{array}{l}0.050 \\
(0.10)\end{array}$ & $\begin{array}{l}0.029 \\
(0.14)\end{array}$ \\
\hline Obse & 1,690 & 1,690 & 1,682 \\
\hline R-squared & 0.060 & 0.157 & 0.175 \\
\hline
\end{tabular}

Robust standard errors in parentheses ${ }^{* * *} \mathrm{p}<0.01,{ }^{* *} \mathrm{p}<0.05,{ }^{*} \mathrm{p}<0.1$ 
Table A3

Probability of school success - Panel data estimates

\begin{tabular}{|c|c|c|c|c|}
\hline DEPENDENT VARIABLE & $\begin{array}{c}(1) \\
\text { Achievement } \\
(2001) \\
\end{array}$ & $\begin{array}{c}(2) \\
\text { Achievement } \\
(2001) \\
\end{array}$ & $\begin{array}{c}(3) \\
\text { Achievement } \\
(2001)\end{array}$ & $\begin{array}{c}\text { (4) } \\
\text { Differenced } \\
\text { Achievement }\end{array}$ \\
\hline \multicolumn{5}{|l|}{ INDEPENDENT VARIABLES } \\
\hline \multicolumn{5}{|l|}{ Child characteristics } \\
\hline Interest in school - medium (1998) & $\begin{array}{l}0.20 * * * \\
(0.045)\end{array}$ & $\begin{array}{l}0.11 \\
(0.071)\end{array}$ & $\begin{array}{l}0.084 \\
(0.063)\end{array}$ & $\begin{array}{l}-0.080 \\
(0.058)\end{array}$ \\
\hline Interest in school - high (1998) & $\begin{array}{l}0.47 * * * \\
(0.071)\end{array}$ & $\begin{array}{l}0.26 * * * \\
(0.098)\end{array}$ & $\begin{array}{l}0.22^{* *} \\
(0.10)\end{array}$ & $\begin{array}{l}-0.031 \\
(0.037)\end{array}$ \\
\hline Achievement (1998) & & $\begin{array}{l}0.76^{* * *} \\
(0.023)\end{array}$ & $\begin{array}{l}0.67 * * * \\
(0.043)\end{array}$ & \\
\hline Sex $($ male $=1)$ & & & $\begin{array}{l}-0.081^{* * *} \\
(0.022)\end{array}$ & $\begin{array}{l}-0.047 * * * \\
(0.014)\end{array}$ \\
\hline Age & & & $\begin{array}{l}-0.37 * * * \\
(0.11)\end{array}$ & $\begin{array}{l}-0.21^{* * *} \\
(0.064)\end{array}$ \\
\hline Pre-school attendance & & & $\begin{array}{l}0.0082 \\
(0.024)\end{array}$ & $\begin{array}{l}0.0058 \\
(0.016)\end{array}$ \\
\hline Time to school & & & $\begin{array}{l}0.00066 \\
(0.0010)\end{array}$ & $\begin{array}{l}0.00018 \\
(0.00066)\end{array}$ \\
\hline Family/socio-economic characteristics & & & & \\
\hline Head of household's schooling 5-9 years & & & $\begin{array}{l}0.11 * * * \\
(0.022)\end{array}$ & $\begin{array}{l}0.062^{* * *} \\
(0.014)\end{array}$ \\
\hline Head of household's schooling $>9$ years & & & $\begin{array}{l}0.14 * * * \\
(0.027)\end{array}$ & $\begin{array}{l}0.075^{* * *} \\
(0.017)\end{array}$ \\
\hline Single parent family & & & $\begin{array}{l}-0.064 \\
(0.054)\end{array}$ & $\begin{array}{l}-0.0037 \\
(0.028)\end{array}$ \\
\hline Household size & & & $\begin{array}{l}-0.011 \\
(0.0096)\end{array}$ & $\begin{array}{l}-0.0049 \\
(0.0060)\end{array}$ \\
\hline Household income & & & $\begin{array}{l}0.019 * * \\
(0.0088)\end{array}$ & $\begin{array}{l}0.010^{*} \\
(0.0056)\end{array}$ \\
\hline Reduction in income $=1$ & & & $\begin{array}{l}-0.041 \\
(0.031)\end{array}$ & $\begin{array}{l}-0.035^{*} \\
(0.021)\end{array}$ \\
\hline Number of rooms in house & & & $\begin{array}{l}0.043^{* * *} \\
(0.014)\end{array}$ & $\begin{array}{l}0.019^{* *} \\
(0.0089)\end{array}$ \\
\hline Adequate housing conditions & & & $\begin{array}{l}0.044 \\
(0.038)\end{array}$ & $\begin{array}{l}0.015 \\
(0.024)\end{array}$ \\
\hline Good housing conditions & & & $\begin{array}{l}0.084^{*} \\
(0.045)\end{array}$ & $\begin{array}{l}0.029 \\
(0.027)\end{array}$ \\
\hline Family has a plot $=1$ & & & $\begin{array}{l}-0.012 \\
(0.025)\end{array}$ & $\begin{array}{l}-0.0033 \\
(0.016)\end{array}$ \\
\hline Educational inputs & & & & \\
\hline Teachers with bachelors degree or less & & & $\begin{array}{l}-0.38^{*} \\
(0.20)\end{array}$ & $\begin{array}{l}-0.24 * \\
(0.12)\end{array}$ \\
\hline Teachers with temporary contracts & & & $\begin{array}{l}-17.2 \\
(23.1)\end{array}$ & $\begin{array}{l}-8.30 \\
(14.7)\end{array}$ \\
\hline Pupil-teacher ratio & & & $\begin{array}{l}-0.0081 \\
(0.0074)\end{array}$ & $\begin{array}{l}-0.0060 \\
(0.0044)\end{array}$ \\
\hline Pupils per school & & & $\begin{array}{l}0.0014^{* * *} \\
(0.00022)\end{array}$ & $\begin{array}{l}0.00058^{* * *} \\
(0.00013)\end{array}$ \\
\hline Observations & 1690 & 1690 & 1,682 & 1,666 \\
\hline Pseudo $\mathrm{R}^{2}$ & 0.049 & 0.2872 & 0.453 & 0.184 \\
\hline
\end{tabular}

Notes: Other variables included in the specification are age-squared, an indicator if the child is not the son of the head of the household and another if the household owns a plot, a set of regional indicators for the province of residence, indicators for residing in urban, semi-rural and rural areas. Probit marginal effects reported. Robust standard errors in parentheses, ${ }^{* * *} \mathrm{p}<0.01,{ }^{* *} \mathrm{p}<0.05,{ }^{*} \mathrm{p}<0.1$. 